\title{
AN UPDATED CHECKLIST AND CHARACTERISATION OF THE ICHTHYOFAUNA (ELASMOBRANCHII AND ACTINOPTERYGII) OF THE LAGUNA DE TAMIAHUA, VERACRUZ, MEXICO
}

\author{
Andrea RAZ-GUZMÁN ${ }^{1 *}$, Leticia HUIDOBRO², and Virginia PADILLA ${ }^{3}$ \\ ${ }^{1}$ Posgrado en Ciencias del Mar y Limnología, Universidad Nacional Autónoma de México, Ciudad de México \\ ${ }^{2}$ Instituto Nacional de Pesca y Acuacultura, SAGARPA, Ciudad de México \\ ${ }^{3}$ Facultad de Ciencias, Universidad Nacional Autónoma de México, Ciudad de México
}

Raz-Guzmán A., Huidobro L., Padilla V. 2018. An updated checklist and characterisation of the ichthyofauna (Elasmobranchii and Actinopterygii) of the Laguna de Tamiahua, Veracruz, Mexico. Acta Ichthyol. Piscat. 48 (4): 341-362.

\begin{abstract}
Background. Laguna de Tamiahua is ecologically and economically important as a nursery area that favours the recruitment of species that sustain traditional fisheries. It has been studied previously, though not throughout its whole area, and considering the variety of habitats that sustain these fisheries, as well as an increase in population growth that impacts the system. The objectives of this study were to present an updated list of fish species, data on special status, new records, commercial importance, dominance, density, ecotic position, and the spatial and temporal distribution of species in the lagoon, together with a comparison of Tamiahua with 14 other Gulf of Mexico lagoons.

Materials and methods. Fish were collected in August and December 1996 with a Renfro beam net and an otter trawl from different habitats throughout the lagoon. The species were identified, classified in relation to special status, new records, commercial importance, density, dominance, ecotic position, and spatial distribution patterns. Results. The 45 species collected by the authors plus an additional 125 species previously reported provided an updated list of 170 species. Families with the highest number of species were Sciaenidae (16 spp.) and Gobiidae (12 spp.). Poecilia latipunctata Meek, 1904 is endemic to Mexico and in danger of extinction and Hippocampus zosterae Jordan et Gilbert, 1882 is under special protection. New records are Ariopsis assimilis (Günther, 1864), Mugil liza Valenciennes, 1836, Symphurus civitatium Ginsburg, 1951, and Aluterus schoepfii (Walbaum, 1792). Commercially important species are Lutjanus griseus (Linnaeus, 1758), Lutjanus synagris (Linnaeus, 1758), Bairdiella chrysoura (Lacepède, 1802), Cynoscion arenarius Ginsburg, 1930, Cynoscion nebulosus (Cuvier, 1830), Cynoscion nothus (Holbrook, 1848), and Archosargus probatocephalus (Walbaum, 1792). The highest densities were recorded for Eucinostomus melanopterus (Bleeker, 1863), Eucinostomus gula (Quoy et Gaimard, 1824), Syngnathus scovelli (Evermann et Kendall, 1896), Achirus lineatus (Linnaeus, 1758), and Cathorops aguadulce (Meek, 1904). The dominant species were Cathorops melanopus (Günther, 1864), Citharichthys spilopterus Günther, 1862, and E. gula.

Conclusions. The majority of the fishes collected in the Laguna de Tamiahua favoured seagrass beds along 'costa mar', the islands Juan A. Ramírez and del Idolo, and areas near the northern and southern inlets. Of the 170 fish species, 10 were present in the 15 compared lagoons, five were recorded only in Tamiahua, and the other species were present in 2 to 14 lagoons. The lagoons most similar to Tamiahua regarding the composition of ichthyofauna were Tampamachoco, Términos, Alvarado, and Madre. This study contributed to the knowledge on a lagoon that sustains local and regional fisheries on which local communities depend.
\end{abstract}

Keywords: fish, commercial importance, local distribution, Laguna de Tamiahua, Mexico

\section{INTRODUCTION}

Estuarine fishes form a highly diverse group that includes freshwater, permanent estuarine, euryhaline marine, and stenohaline marine species that migrate from one system to the other, while taking advantage of the seagrass beds as nursery areas for growth, reproduction, and feeding (Yáñez-
Arancibia et al. 1988, Seitz et al. 2014). Fish actively transmit energy through trophic chains, linking detritus and detritivores to higher trophic levels, storing energy within the ecosystem, and exchanging it with neighbouring areas as importers and exporters (Castro-Aguirre et al. 1999). Fish support local and regional fisheries (Yáñez-Arancibia and 
Aguirre-León 1988, Seitz et al. 2014) and are an important source of food, vitamins (cod, tuna, shark), preserves, and industrial products (cattle feed). Along with crustaceans (Raz-Guzmán and Sánchez 1996b, Barba Macías 1999) and molluscs (García-Cubas and Reguero 2004, 2007), fish are the dominant community components with respect to abundance and species richness in the Mexican coastal lagoons of the Gulf of Mexico (Franco-López et al. 2012, Aguirre-León et al. 2014, Ayala-Pérez et al. 2015, SánchezRamírez and Ocaña-Luna 2015, Ocaña-Luna and SánchezRamírez 2016).

Estuaries are subject to serious problems generated by urban, agricultural, and industrial pollution, as well as by overfishing, tourism, and silting up caused by sediment carried down the river. Constituting bridges between watersheds and the sea, they represent a high biodiversity. Approximately 15 estuarine systems are located along the south-western Gulf of Mexico coasts. Of these estuarine systems, the third largest and a RAMSAR site since November 2005, is Laguna de Tamiahua in the state of Veracruz. This lagoon is ecologically and economically important as its nursery areas provide ideal conditions (protected shallow areas, submerged aquatic vegetation, mangrove roots, poly-euhaline and warm water) for the reproduction, feeding and growth of aquatic species. They also favour the recruitment of freshwater, estuarine, and marine species, including those that sustain traditional fisheries such as the oyster Crassostrea virginica, the shrimps Litopenaeus setiferus and Farfantepenaeus aztecus, the blue crab Callinectes sapidus, and the mullets Mugil cephalus Linnaeus, 1758 and Mugil curema Valenciennes, 1836. The salinity gradient, variety of substrates, submerged aquatic vegetation, and mangroves generate a high heterogeneity of habitats that are available throughout the lagoon for resident and visiting species that form communities with different physical and trophic structures (Raz-Guzmán and Sánchez 1996a, Sánchez et al. 1996). As a result of this, high abundances have been recorded for invertebrates (Raz-Guzmán and Barba 2000, Cid and Raz Guzmán 2011, Raz-Guzmán and Soto 2017) and fish (Gaspar-Dillanes and Barba-Torres 2004, Sanvicente-Añorve et al. 2011, Ocaña-Luna and SánchezRamírez 2016) in this lagoon.

The objectives of this study were to present an updated list of fish species of the Laguna de Tamiahua, based on our own data and on data compiled through an intensive search in the literature, together with data on special status, new records, commercial importance, density, dominance, ecotic position, and the spatial and temporal distribution of the collected fish in the lagoon, and to compare the fish species of this lagoon with those reported for 14 other Mexican lagoons of the Gulf of Mexico (Términos, Mecoacán, Redonda, Machona, Carmen, Ostión, Sontecomapan, Alvarado, Mandinga, La Mancha, Chica-Grande, Tampamachoco, Pueblo Viejo, and Madre). Among the ichthyofaunal studies that have been carried out in some of these lagoons are those of Ayala-Pérez et al. $(2003,2015)$ for the Laguna de Términos, Rodríguez-Varela et al. (2010) for the Laguna Sontecomapan, Chavez-Lopez and Franco-Lopez (1993), Chavez López et al. (2005), Franco-López et al. (2012), and Carrillo-Alejandro et al. (2014b) for the Laguna de Alvarado, Pérez (2007) and Díaz-Ruiz et al. (2018) for the Laguna La Mancha, Pérez (2007), and Aguirre-León et al. (2014) for the Laguna Chica-Grande, Pérez-Hernández and Torres-Orozco (2000), and Ocaña-Luna and SánchezRamírez (2003) for the Laguna Tampamachoco, FrancoLópez and Chávez-López (1993), Díaz-Ruiz et al. (2003), Gaspar-Dillanes and Barba-Torres (2004), SanvicenteAñorve et al. (2011), and Ocaña-Luna and SánchezRamírez (2016) for the Laguna de Tamiahua, CastilloRivera and Zárate Hernandez (2001), Castillo-Rivera et al. (2005), and Carrillo-Alejandro et al. (2014a) for the Laguna Pueblo Viejo, and Barba (1999), Raz-Guzmán and Huidobro (2002), Anonymous (2015b), and SánchezRamírez and Ocaña-Luna (2015) for the Laguna Madre. Reséndez-Medina and Kobelkowsky-Díaz (1991) and Castro-Aguirre et al. (1999) recorded data for 14 of the 15 lagoons, while Abarca-Arenas et al. (2012) covered nine of the 15 lagoons.

\section{MATERIALS AND METHODS}

Study area. Laguna de Tamiahua is the third largest coastal lagoon in Mexico with 88000 ha. It is $90 \mathrm{~km}$ long and $22 \mathrm{~km}$ wide. It is located between $21^{\circ} 16^{\prime}-$ $22^{\circ} 05^{\prime} \mathrm{N}$ and $97^{\circ} 23^{\prime}-97^{\circ} 43^{\prime} \mathrm{W}$. It has two inlets, the northern Boca de Tampachichi and the southern Boca de Corazones. The sandy barrier of Cabo Rojo to the east is a zoogeographically significant area as it marks the transition between the Carolinean-Temperate and the Caribbean-Tropical provinces for shallow-water marine species (Thurman 1987). Inside the lagoon are three large islands: Isla Juan A. Ramírez, Isla del Toro, and Isla del Idolo, as well as several small isles. The streams La Laja, Cucharas, San Jerónimo, Tancochín, Tampache, and Milpas provide freshwater along the western banks of the lagoon. The region has a dry season (March-August) and a rainy season (September-February). Salinity is $22 \%{ }^{-}-38 \%{ }^{*}$ in August and $27 \%{ }^{-}-32 \%$ in December, water temperature is $28-34^{\circ} \mathrm{C}$ in August and $24-27^{\circ} \mathrm{C}$ in December and maximum depth is $4 \mathrm{~m}$ (authors' data). The lagoon may be divided into three regions: north, central, and south. The northern and southern regions receive tidal-borne seawater, while the central region receives freshwater from the creeks and streams. Two large environmentally distinct areas may also be identified: one along the inner margin of the sand barrier where the shoal grass Halodule wrightii forms meadows (locally called 'costa mar') and another along the western margin of the lagoon where green, red, and brown macroalgae form dense mats (locally called 'costa tierra'). The former has larger shallow areas and is protected from the south-easterly winds, while the latter is generally deeper and more exposed to the winds. The habitats in the two 
areas are thus quite different. Mangroves of Rhizophora mangle, Avicennia germinans, Laguncularia racemosa, and Conocarpus erectus are found mostly in the southern region of the lagoon (Fig. 1).

Sampling design and data analyses. Sampling in the Laguna de Tamiahua took place in August and December 1996 in order to represent the two main climatic seasons of the region. Sampling localities were distributed throughout the lagoon, with 34 localities in August and 23 in December (Fig. 1). These were selected considering the spatial heterogeneity provided by the submerged aquatic vegetation, the streams, the islands, and the inlets. The names of the localities where fish were collected are included in Fig. 1.

Epifauna and submerged aquatic vegetation (SAV) were collected, always following the same procedure, with two different nets in order to obtain both smaller-shallower (Renfro beam net, $1 \mathrm{~mm}$ mesh size, $50 \mathrm{~m}^{2}$ sampling area, Renfro 1962) and larger-deeper (otter trawl, $1 \mathrm{~cm}$ mesh size, 1.5-3 min CPUE) fish specimens from different habitats. The SAV species were recognised at the group level and discarded. The fish samples were preserved in $10 \%$ formalin in the field and replaced with $70 \%$ alcohol in the lab. The species were identified following McEachran and Fechhelm (1998, 2005), Castro-Aguirre et al. (1999), Miller et al. (2005), and Froese and Pauly (2018). The specimens were then deposited in the Colección Nacional de Peces, Instituto de Biología, UNAM. The species that were collected in this study plus those reported for this lagoon in other studies (see below in Results) provided a species list that was taxonomically updated following Fricke et al. (2018). The phylogenetic arrangement of the Orders follows Nelson et al. (2016) and the families, genera, and species are presented in alphabetical order. The common names of the species used throughout the text were taken from FishBase (Froese and Pauly 2018). The Norma Oficial Mexicana (Anonymous 2010) and the IUCN Red List of Threatened Species were consulted to identify the Laguna de Tamiahua fish species under a special status. New records and commercially important
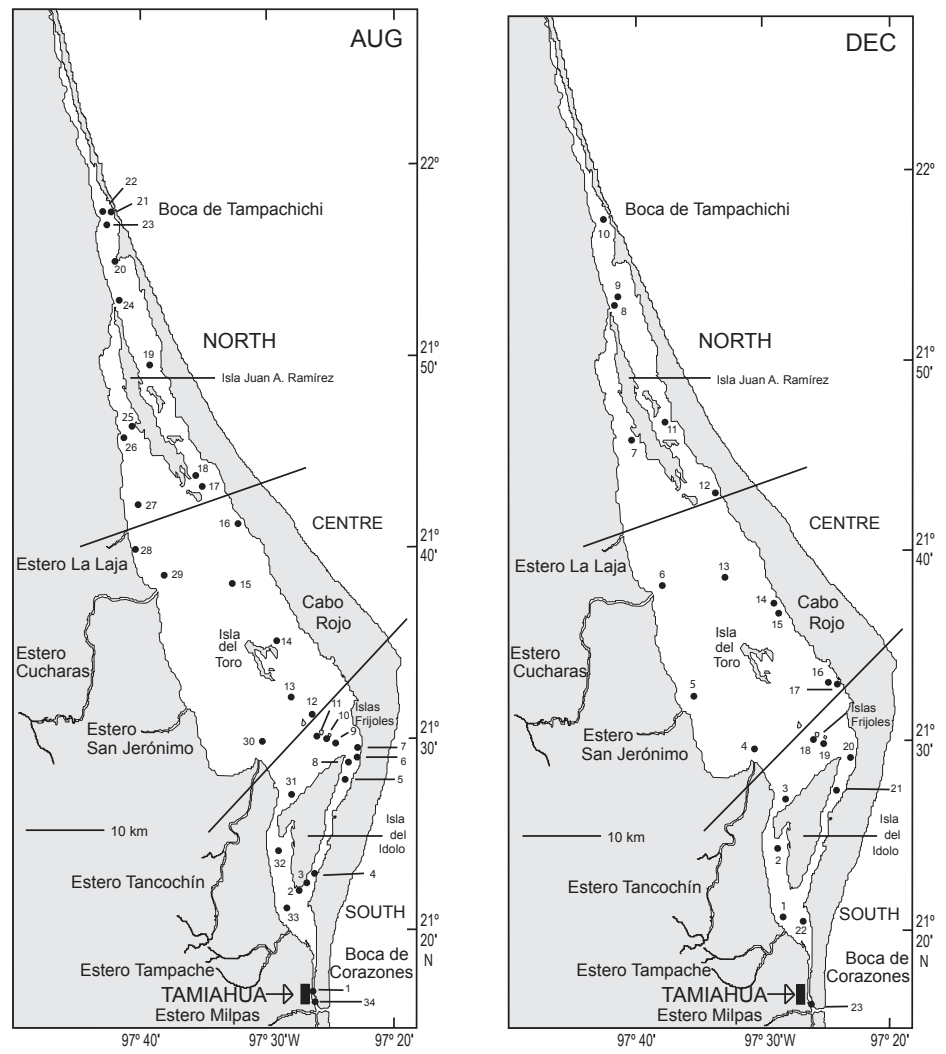

Fig. 1. Laguna de Tamiahua, Gulf of Mexico, Mexico - toponymy, regions, and the sampling stations where fish were collected in 1996; August = left: $2=$ southern point of Isla del Idolo, $3=$ southern point of Isla del Idolo, $5=$ off Isla del Idolo, 6 = Nuestra Señora, 7 = Nuestra Señora, $9=$ between Punta de Martínez and Islas Frijoles, $10=$ Isla Frijoles Este, 13 = between Isla Pájaros and Isla del Toro, $16=$ La Restinga, $17=$ north of Isla Burros, $18=$ south point of Isla Juan A. Ramírez, 19 = north of Isla Frontón, 20 = southeast of Las Chacas, 21 = Boca de Tampachichi, 22 = west of Boca de Tampachichi, 23 = Las Chacas, 24 = northern point of Isla Juan A. Ramírez, $27=$ northeast of La Laja, 29 = off Estero Cucharas, $30=$ off Estero Tancochín, $31=$ Los Pipianes, $32=$ Ensenada Grande, $33=$ off Estero Tampache, 34 = Boca de Corazones; December $=$ right: $1=$ off Estero Tampache, $2=$ Ensenada Grande, $5=$ off Estero San Jerónimo, 6 = off Estero Cucharas, $8=$ northern point of Isla Juan A. Ramírez, $9=$ northern point of Isla Juan A. Ramírez, 10 = Boca de Tampachichi, 14 = north-east of Isla del Toro, 15 = north-east of Isla del Toro, 18 = Isla Frijoles Este, 20 = Nuestra Señora, 21 = off Isla del Idolo, 22 = La Lata, 23 = Boca de Corazones. 
fish species were identified. The specimens of each species collected in the lagoon in this study were counted in order to obtain density data as ind $\cdot \mathrm{m}^{-2}$ for the Renfro and ind - $\min ^{-1}$ for the otter trawl, for August and December. An Olmstead-Tükey dominance analysis (Sokal and Rohlf 1995) was applied to the density and spatial frequency (number of localities in the lagoon in which each species was present) data to identify the dominant, frequent, local, and rare species. The ecotic position of the species was included following the criteria of Castro-Aguirre et al. (1999). Maps were prepared with a Surfer 10 programme (Version 10.1.561. Golden Software, USA) to graphically represent the spatial and temporal distribution of the fish species collected with the two nets, and spatial distribution patterns were identified. The updated list of fish species of the Laguna de Tamiahua was then compared with records of these species (both ichthyoplankton and adults) for 14 other lagoons along the Mexican coasts of the Gulf of Mexico (Términos, Mecoacán, Redonda, Machona, Carmen, Ostión, Sontecomapan, Alvarado, Mandinga, La Mancha, Chica-Grande, Tampamachoco, Pueblo Viejo, and Laguna Madre), reported from 1991 to the present in 26 studies. A cluster analysis based on Jaccard's similarity index (Krebs 2008) was then carried out to identify similar lagoons with respect to ichthyofauna.

\section{RESULTS}

During this study, 514 fish specimens, representing 42 species, 31 genera, 20 families, 14 orders, and 2 classes were collected in the Laguna de Tamiahua. Of these, 357 specimens and 28 species were collected in August and 157 specimens and 28 species were collected in December. In addition, 14 species were collected only on 14 August, only in December, and 14 in both months. Added to these species, but excluded from the analyses, were 125 additional species that were reported for this lagoon in eight other studies (Reséndez-Medina and KobelkowskyDíaz 1991, Franco-López and Chavez-López 1993, Castro-Aguirre et al. 1999, Díaz-Ruiz et al. 2003, GasparDillanes and Barba-Torres 2004, Sanvicente-Añorve et al. 2011, Abarca-Arenas et al. 2012, Ocaña-Luna and Sánchez-Ramírez 2016) and three species of the authors' unpublished data. The species collected by the authors in this study are indicated in the species list with a $\bullet$, together with the month (A for August and D for December) of the collection, and the authors' unpublished data are indicated with a U. This compilation provides a total of 170 species, 110 genera, 55 families, 34 orders, 2 subclasses, 2 classes, and 2 superclasses, for a taxonomically updated species list of the ichthyofauna of the Laguna de Tamiahua, as follows:

\section{Phylum Chordata}

Subphylum Vertebrata

Superclass Gnathostomata

Class Elasmobranchii

Order Carcharhiniformes

Family Triakidae

Mustelus canis (Mitchill, 1815)
Order Torpediniformes

Family Narcinidae

Narcine brasiliensis (Olfers, 1831)

Order Rajiformes

Family Rajidae

Rostroraja texana (Chandler, 1921)

Order Pristiformes

Family Rhinobatidae

Pseudobatos lentiginosus (Garman, 1880)

Order Myliobatiformes

Family Dasyatidae

Hypanus americanus (Hildebrand et Schroeder, 1928)

Hypanus sabinus (Lesueur, 1824) OD

Family Urotrygonidae

Urobatis jamaicensis (Cuvier, 1816)

Superclass Osteichthyes

Class Actinopterygii

Subclass Neopterygii

Division Teleostei

Order Lepisosteiformes

Family Lepisosteidae Atractosteus spatula (Lacepède, 1803)

Order Elopiformes

Family Elopidae Elops affinis Regan, 1909

Elops saurus Linnaeus, 1766

Family Megalopidae Megalops atlanticus Valenciennes, 1847

Order Anguilliformes

Family Ophichthidae Myrophis punctatus Lütken, 1852

Ophichthus gomesii (Castelnau, 1855)

Order Clupeiformes

Family Clupeidae

Brevoortia gunteri Hildebrand, 1948

Brevoortia patronus Goode, 1878

Dorosoma cepedianum (Lesueur, 1818)

Dorosoma petenense (Günther, 1867)

Harengula clupeola (Cuvier, 1829)

Harengula jaguana Poey, 1865

Opisthonema oglinum (Lesueur, 1818)

Family Engraulidae

Anchoa hepsetus (Linnaeus, 1758)

Anchoa lyolepis (Evermann et Marsh, 1900)

Anchoa mitchilli (Valenciennes, 1848)

Cetengraulis edentulus (Cuvier, 1829)

Order Characiformes

Family Characidae Astyanax mexicanus (De Filippi, 1853)

Order Siluriformes

Family Ariidae

Ariopsis assimilis (Günther, 1864) U

Ariopsis felis (Linnaeus, 1766) A

Bagre marinus (Mitchill, 1815) D D

Cathorops aguadulce (Meek, 1904) A, D

Cathorops melanopus (Günther, 1864) D D

Cathorops spixii (Agassiz, 1829)

Order Aulopiformes

Family Synodontidae 
Synodus foetens (Linnaeus, 1766)

Order Batrachoidiformes

Family Batrachoididae

Opsanus beta (Goode et Bean, 1880) A, D

Porichthys plectrodon Jordan et Gilbert, 1882

Order Gobiiformes

Family Eleotridae

Dormitator maculatus (Bloch, 1792)

Eleotris amblyopsis (Cope, 1871)

Eleotris pisonis (Gmelin, 1789) D

Gobiomorus dormitor Lacepède, 1800

Family Gobiidae

Bathygobius soporator (Valenciennes, 1837)

Ctenogobius boleosoma (Jordan et Gilbert, 1882) O D

Ctenogobius shufeldti (Jordan et Eigenmann, 1887)

Evorthodus lyricus (Girard, 1858)

Gobioides broussonnetii Lacepède, 1800

Gobionellus hastatus Girard, 1858 D

Gobionellus oceanicus (Pallas, 1770) D D

Gobiosoma bosc (Lacepède, 1800) A

Gobiosoma robustum Ginsburg, 1933 A, D

Lophogobius cyprinoides (Pallas, 1770)

Microgobius gulosus (Girard, 1858)

Microgobius thalassinus (Jordan et Gilbert, 1883)

Order Mugiliformes

Family Mugilidae

Mugil cephalus Linnaeus, 1758

Mugil curema Valenciennes, 1836

Mugil liza Valenciennes, $1836 \mathbf{U}$

Mugil trichodon Poey, 1875

Order Cichliformes

Family Cichlidae

Coptodon rendalli (Boulenger, 1897)

Herichthys cyanoguttatus Baird et Girard, 1854

Herichthys labridens (Pellegrin, 1903)

Oreochromis aureus (Steindachner, 1864)

Oreochromis mossambicus (Peters, 1852) O D

Order Blenniformes

Family Blenniidae

Chasmodes bosquianus (Lacepède, 1800)

Hypleurochilus geminatus (Wood, 1825)

Hypsoblennius hentz (Lesueur, 1825)

Lupinoblennius nicholsi (Tavolga, 1954)

Order Gobiesociformes

Family Gobiesocidae

Gobiesox strumosus Cope, 1870

Order Atheriniformes

Family Atherinopsidae

Membras martinica (Valenciennes, 1835)

Membras vagrans (Goode et Bean, 1879)

Menidia beryllina (Cope, 1867)

Menidia peninsulae (Goode et Bean, 1879)

Order Beloniformes

Family Belonidae

Strongylura marina (Walbaum, 1792)

Strongylura notata (Poey, 1860)

Strongylura timucu (Walbaum, 1792)

Family Hemiramphidae

Hemiramphus brasiliensis (Linnaeus, 1758)
Hyporhamphus meeki Banford et Collette, 1993

Hyporhamphus roberti (Valenciennes, 1847)

Hyporhamphus unifasciatus (Ranzani, 1842)

Order Cyprinodontiformes

Family Cyprinodontidae

Cyprinodon variegatus Lacepède, 1803

Family Fundulidae

Fundulus grandis Baird et Girard, 1853

Lucania parva (Baird et Girard, 1855) A A

Family Poeciliidae

Gambusia regani Hubbs, 1926

Poecilia latipunctata Meek, 1904

Poecilia mexicana Steindachner, 1863

Order Carangiformes

Family Echeneidae

Echeneis naucrates Linnaeus, 1758

Family Carangidae

Caranx hippos (Linnaeus, 1766)

Caranx latus Agassiz, 1831

Chloroscombrus chrysurus (Linnaeus, 1766) - A

Hemicaranx amblyrhynchus (Cuvier, 1833)

Oligoplites saurus (Bloch et Schneider, 1801)

Selene setapinnis (Mitchill, 1815)

Selene vomer (Linnaeus, 1758)

Trachinotus carolinus (Linnaeus, 1766)

Trachinotus falcatus (Linnaeus, 1758)

Order Pleuronectiformes

Family Paralichthyidae

Citharichthys arctifrons Goode, 1880

Citharichthys spilopterus Günther, 1862 A, D

Syacium gunteri Ginsburg, 1933

Family Achiridae

Achirus lineatus (Linnaeus, 1758) A, D

Trinectes maculatus (Bloch et Schneider, 1801)

Family Cynoglossidae

Symphurus civitatium Ginsburg, 1951 ○ D

Symphurus plagiusa (Linnaeus, 1766)

Order Syngnathiformes

Family Syngnathidae

Hippocampus zosterae Jordan et Gilbert, 1882 A

Microphis lineatus (Kaup, 1856)

Syngnathus floridae (Jordan et Gilbert, 1882) A A, D

Syngnathus louisianae Günther, 1870 A A, D

Syngnathus scovelli (Evermann et Kendall, 1896) A, D

Order Scombriformes

Family Scombridae

Scomberomorus maculatus (Mitchill, 1815)

Family Stromateidae

Peprilus burti Fowler, 1944

Peprilus triacanthus (Peck, 1804)

Family Trichiuridae

Trichiurus lepturus Linnaeus, 1758 A

Order Trachiniformes

Family Uranoscopidae

Astroscopus y-graecum (Cuvier, 1829)

Order Labriformes

Family Labridae

Lachnolaimus maximus (Walbaum, 1792)

Order Perciformes 
Family Centropomidae Centropomus ensiferus Poey, 1860 D D Centropomus parallelus Poey, 1860 Centropomus pectinatus Poey, 1860 Centropomus poeyi Chávez, 1961 Centropomus undecimalis (Bloch, 1792)

Family Serranidae

Epinephelus guttatus (Linnaeus, 1758)

Family Lutjanidae

Lutjanus analis (Cuvier, 1828)

Lutjanus apodus (Walbaum, 1792)

Lutjanus campechanus (Poey, 1860)

Lutjanus cyanopterus (Cuvier, 1828)

Lutjanus griseus (Linnaeus, 1758) A

Lutjanus synagris (Linnaeus, 1758) ○ D

Family Gerreidae

Diapterus auratus Ranzani, 1840

Diapterus rhombeus (Cuvier, 1829) A

Eucinostomus argenteus Baird et Girard, 1855 D

Eucinostomus gula (Quoy et Gaimard, 1824) A

Eucinostomus jonesii (Günther, 1879)

Eucinostomus melanopterus (Bleeker, 1863)

Eugerres plumieri (Cuvier, 1830)

Gerres cinereus (Walbaum, 1792) A

Ulaema lefroyi (Goode, 1874)

Family Haemulidae

Conodon nobilis (Linnaeus, 1758) D D

Haemulon sciurus (Shaw, 1803)

Orthopristis chrysoptera (Linnaeus, 1766) A A

Pomadasys crocro (Cuvier, 1830)

Order Scorpaeniformes

Family Scorpaenidae

Scorpaena plumieri Bloch, 1789

Family Triglidae

Prionotus tribulus Cuvier, 1829

Order Moroniformes

Family Ephippidae

Chaetodipterus faber (Broussonet, 1782) A

Order Acanthuriformes

Family Sciaenidae

Bairdiella chrysoura (Lacepède, 1802) A, D

Bairdiella ronchus (Cuvier, 1830) A, D

Cynoscion arenarius Ginsburg, 1930 D

Cynoscion nebulosus (Cuvier, 1830) A, D

Cynoscion nothus (Holbrook, 1848) A

Larimus fasciatus Holbrook, 1855

Leiostomus xanthurus Lacepède, 1802

Menticirrhus americanus (Linnaeus, 1758) A

Menticirrhus littoralis (Holbrook, 1847)

Menticirrhus saxatilis (Bloch et Schneider, 1801)

Micropogonias furnieri (Desmarest, 1823)

Micropogonias undulatus (Linnaeus, 1766)

Pogonias cromis (Linnaeus, 1766)

Sciaenops ocellatus (Linnaeus, 1766)

Stellifer lanceolatus (Holbrook, 1855)

Umbrina coroides Cuvier, 1830

Order Spariformes

Family Sparidae

Archosargus probatocephalus (Walbaum, 1792)
Archosargus rhomboidalis (Linnaeus, 1758)

Lagodon rhomboides (Linnaeus, 1766) A A, D

Stenotomus chrysops (Linnaeus, 1766)

Order Lophiiformes

Family Antennariidae

Antennarius multiocellatus (Valenciennes, 1837)

Order Tetraodontiformes

Family Monacanthidae

Aluterus schoepfii (Walbaum, 1792) U

Aluterus scriptus (Osbeck, 1765)

Stephanolepis hispidus (Linnaeus, 1766)

Family Tetraodontidae

Sphoeroides nephelus (Goode et Bean, 1882)

Sphoeroides parvus Shipp et Yerger, 1969

Sphoeroides spengleri (Bloch, 1785)

Sphoeroides testudineus (Linnaeus, 1758)

Family Diodontidae

Chilomycterus schoepfii (Walbaum, 1792)

Diodon hystrix Linnaeus, 1758

The following two families are 'inserta sedi' following Nelson et al. (2016) phylogenetic arrangement of the Orders:

Family Polynemidae

Polydactylus octonemus (Girard, 1858)

Family Sphyraenidae

Sphyraena barracuda (Edwards, 1771)

Sphyraena guachancho Cuvier, 1829

The family with most species is Sciaenidae with 16 , followed by Gobiidae with 12, Carangidae and Gerreidae with nine each, Clupeidae with seven, and Ariidae and Lutjanidae with six each. The other families are represented by one to five species each.

Only two fish species occupy a special status in the Norma Oficial Mexicana (Anonymous 2010): Poecilia latipunctata is endemic to Mexico and in danger of extinction and Hippocampus zosterae is under special protection (Anonymous 2010). Both are also included in the IUCN Red List of Threatened Species: P. latipunctata as endemic to Mexico and critically endangered (ContrerasBalderas and Almada-Villela 1996) and H. zosterae as of least concern (Masonjones et al. 2017).

The findings of four species constitute new records for the Laguna de Tamiahua. Only two specimens of Symphurus civitatium were collected in only one locality (Ensenada Grande) along the western margin of Isla del Idolo in December with the otter trawl. Ariopsis assimilis, Mugil liza, and Aluterus schoepfii were collected by the authors previously, but these records have not yet been published.

Of the 42 species collected in this study, Lutjanus griseus, L. synagris, Bairdiella chrysoura, Cynoscion arenarius, C. nebulosus, C. nothus, and Archosargus probatocephalus are commercially important.

The species with the greatest density values in the lagoon are the following (Table 1). RENFRO, August: Eucinostomus melanopterus ( 1 ind $\cdot \mathrm{m}^{-2}$ ), Syngnathus scovelli (0.98 ind · $\left.\mathrm{m}^{-2}\right)$, and Cynoscion nebulosus $\left(0.72\right.$ ind $\left.\cdot \mathrm{m}^{-2}\right)$. December: Opsanus beta $\left(0.6\right.$ ind $\left.\cdot \mathrm{m}^{-2}\right)$. OTTER TRAWL, August: 
Eucinostomus gula (15.32 ind $\left.\cdot \mathrm{min}^{-1}\right)$, Achirus lineatus (13.3 ind $\left.\cdot \mathrm{min}^{-1}\right)$, Cathorops aguadulce $\left(11.3\right.$ ind $\left.\cdot \mathrm{min}^{-1}\right)$, Citharichthys spilopterus (8.96 ind $\cdot \mathrm{min}^{-1}$ ), and Diapterus rhombeus (7.99 ind $\left.\cdot \mathrm{min}^{-1}\right)$. December: Bairdiella chrysoura $\left(6.66\right.$ ind $\left.\cdot \mathrm{min}^{-1}\right)$, C. spilopterus $\left(6.65\right.$ ind $\left.\cdot \mathrm{min}^{-1}\right)$, A. lineatus $\left(6.64\right.$ ind $\left.\cdot \mathrm{min}^{-1}\right)$ and Gobiosoma robustum $\left(6\right.$ ind $\left.\cdot \mathrm{min}^{-1}\right)$.
The Olmstead-Tükey dominance test established Cathorops melanopus, Citharichthys spilopterus, and Eucinostomus gula as the dominant species. Hypanus sabinus and Hippocampus zosterae were spatially frequent, Diapterus rhombeus had a high density and low spatial frequency, 25 species were rare and the other

Table 1

Density and ecotic position of the fish species collected in August and December 1996 in the Laguna de Tamiahua, Gulf of Mexico, Mexico

\begin{tabular}{|c|c|c|c|c|c|}
\hline \multirow[b]{2}{*}{ Species } & \multicolumn{4}{|c|}{ Density } & \multirow{2}{*}{ Ecotic position } \\
\hline & $\begin{array}{c}\text { Aug R } \\
{\left[\text { ind } \cdot \mathrm{m}^{-2}\right]}\end{array}$ & $\begin{array}{c}\text { Aug OT } \\
{\left[\text { ind } \cdot \mathrm{min}^{-1}\right]}\end{array}$ & $\begin{array}{c}\text { Dec R } \\
{\left[\text { ind } \cdot \mathrm{m}^{-2}\right]}\end{array}$ & $\begin{array}{c}\text { Dec OT } \\
{\left[\text { ind } \cdot \mathrm{min}^{-1}\right]}\end{array}$ & \\
\hline Hypanus sabinus & & & & 0.99 & 1B \\
\hline Ariopsis felis & 0.22 & 2.65 & & & $2 \mathrm{~A}$ \\
\hline Bagre marinus & & & & 0.33 & $2 \mathrm{~A}$ \\
\hline Cathorops aguadulce & & 11.30 & & 1.66 & $1 \mathrm{~B}$ \\
\hline Cathorops melanopus & & & & 4.32 & $2 \mathrm{~A}$ \\
\hline Opsanus beta & 0.04 & & 0.60 & 2.66 & $2 \mathrm{~A}$ \\
\hline Eleotris pisonis & & & 0.02 & & $1 \mathrm{~B}$ \\
\hline Ctenogobius boleosoma & & & 0.02 & & $2 \mathrm{~A}$ \\
\hline Gobionellus hastatus & & & & 0.33 & $2 \mathrm{~A}$ \\
\hline Gobionellus oceanicus & & & & 0.33 & $2 \mathrm{~B}$ \\
\hline Gobiosoma bosc & 0.02 & & & & $2 \mathrm{~A}$ \\
\hline Gobiosoma robustum & 0.42 & 0.33 & 0.32 & 6.00 & $2 \mathrm{~A}$ \\
\hline Oreochromis mossambicus & & & & 0.33 & FW \\
\hline Lucania parva & 0.02 & & & & $1 \mathrm{~B}$ \\
\hline Chloroscombrus chrysurus & & 0.66 & & & $2 \mathrm{~A}$ \\
\hline Citharichthys spilopterus & & 8.96 & & 6.65 & $2 \mathrm{~A}$ \\
\hline Achirus lineatus & 0.02 & 13.30 & 0.02 & 6.64 & $2 \mathrm{~A}$ \\
\hline Symphurus civitatium & & & & 0.66 & $2 \mathrm{~B}$ \\
\hline Hippocampus zosterae & 0.06 & & & & $2 \mathrm{~B}$ \\
\hline Syngnathus floridae & 0.16 & & 0.02 & 0.66 & $2 \mathrm{~A}$ \\
\hline Syngnathus louisianae & 0.18 & & 0.28 & & $2 \mathrm{~A}$ \\
\hline Syngnathus scovelli & 0.98 & 0.33 & 0.54 & 0.66 & $2 \mathrm{~A}$ \\
\hline Trichiurus lepturus & & 0.66 & & & $2 \mathrm{~B}$ \\
\hline Centropomus ensiferus & & & & 0.33 & $2 \mathrm{~A}$ \\
\hline Lutjanus griseus & 0.02 & & & & $2 \mathrm{~A}$ \\
\hline Lutjanus synagris & & & 0.40 & 1.00 & $2 \mathrm{~B}$ \\
\hline Diapterus rhombeus & & 7.99 & & & $2 \mathrm{~A}$ \\
\hline Eucinostomus argenteus & & & 0.40 & 1.00 & $2 \mathrm{~A}$ \\
\hline Eucinostomus gula & & 15.32 & & & $2 \mathrm{~A}$ \\
\hline Eucinostomus melanopterus & 1.00 & & & 1.33 & $2 \mathrm{~A}$ \\
\hline Gerres cinereus & & 1.00 & & & $2 \mathrm{~A}$ \\
\hline Conodon nobilis & & & & 0.66 & $2 \mathrm{~B}$ \\
\hline Orthopristis chrysoptera & & 0.66 & & & $2 \mathrm{~A}$ \\
\hline Chaetodipterus faber & 0.06 & 0.66 & & & $2 \mathrm{~A}$ \\
\hline Bairdiella chrysoura & 0.30 & 2.99 & 0.40 & 6.66 & $2 \mathrm{~A}$ \\
\hline Bairdiella ronchus & & 3.65 & & 0.33 & $2 \mathrm{~A}$ \\
\hline Cynoscion arenarius & & & & 0.66 & $2 \mathrm{~A}$ \\
\hline Cynoscion nebulosus & 0.72 & 0.66 & 0.06 & 1.00 & $2 \mathrm{~A}$ \\
\hline Cynoscion nothus & & 0.66 & & & $2 \mathrm{~A}$ \\
\hline Menticirrhus americanus & & 0.66 & & & $2 \mathrm{~A}$ \\
\hline Archosargus probatocephalus & 0.06 & 1.00 & 0.40 & 1.00 & $2 \mathrm{~A}$ \\
\hline Lagodon rhomboides & & 1.33 & 0.06 & 0.11 & $2 \mathrm{~A}$ \\
\hline
\end{tabular}

Aug $=$ August, Dec $=$ December, $\mathrm{R}=$ Renfro beam net, $\mathrm{OT}=$ otter trawl; $\mathrm{FW}=$ freshwater, $1 \mathrm{~B}=$ permanent estuarine, $2 \mathrm{~A}=$ euryhaline marine, $2 \mathrm{~B}=$ stenohaline marine; bold type indicates higher density values. 
11 species varied in the classification with the month and the sampling net.

The ecotic position of the species presented 31 euryhaline marine species $(2 \mathrm{~A})$, six stenohaline marine species (2B), four permanent estuarine species (1B), and one freshwater species (FW) (Table 1).

Spatial distribution. RENFRO, August: The majority of species were collected along 'costa mar' in Halodule wrightii beds, as well as near the northern inlet of Boca de Tampachichi (7 spp. loc\#23, 5 spp. loc\#20) and the northern tip of Isla del Idolo (7 spp. loc\#6, $5 \mathrm{spp}$. loc\#10). December: Similarly, the majority of species were collected along 'costa mar', with the greater number north of Isla Juan A. Ramírez (10 spp. loc\#8) in an area rich in macroalgae (Fig. 2). OTTER TRAWL, August: The larger fishes were collected both along 'costa mar' and 'costa tierra', with the greater number of species north of Isla Juan A. Ramírez (8 spp. loc\#24), inside Boca de Tampachichi (6 spp. loc\#22) and near the northern tip of Isla del Idolo (6 spp. loc\#5, 5 spp. loc\#9). One single high-density value (14.33 ind $\cdot \mathrm{min}^{-1}$ ) was recorded for Eucinostomus gula just inside Boca de Tampachichi (loc\#22) in August. December: As in August, fishes were collected along 'costa mar' and 'costa tierra', with the greater number of species north of Isla Juan A. Ramírez (10 spp. loc\#9), along the western margin of Isla del Idolo (9 spp. loc\#2) and near the southern inlet of Boca de Corazones (6 spp. loc\#23). Of special interest is that, of the nine species collected west of Isla del Idolo, five (Bagre marinus, Gobionellus oceanicus, Symphurus civitatium, Conodon nobilis, and Cynoscion arenarius) were recorded only in this locality and this month, all with low densities of 0.33 to 0.66 ind - $\min ^{-1}$ (Fig. 3).

Overall, more species were collected in the south (30 spp.) and north (24 spp.), with the least species in the centre (11 spp.). An analysis of the spatial distribution of the fish in the lagoon, considering the two months and the two nets, revealed six patterns (Table 2). Seven species (marked 1 in the table as SDP = spatial distribution pattern) were widely distributed throughout the lagoon: Cathorops aguadulce, Gobiosoma robustum, Citharichthys spilopterus, Achirus lineatus, Syngnathus scovelli, Bairdiella chrysoura, and Cynoscion nebulosus. Six species (marked 2) were present in the northern and southern regions: Ariopsis felis, Opsanus beta, Hippocampus zosterae, Eucinostomus gula, E. melanopterus, and B. ronchus. Three species (marked 3)
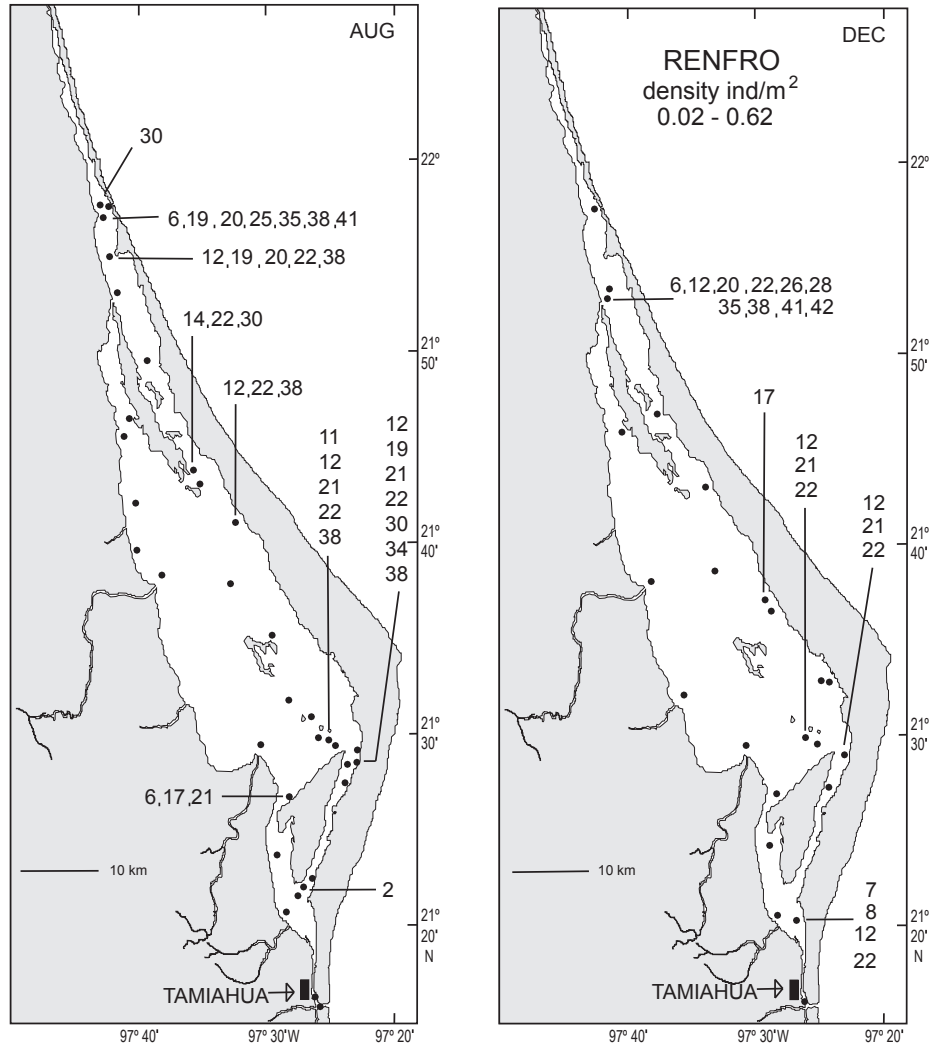

Fig. 2. Laguna de Tamiahua, Gulf of Mexico, Mexico - fish sampling in 1996 with a Renfro beam net; August = left: 2 = Ariopsis felis, $6=$ Opsanus beta, $11=$ Gobiosoma bosc, $12=$ Gobiosoma robustum, $14=$ Lucania parva, 17=Achiruslineatus, $19=$ Hippocampuszosterae, $20=$ Syngnathusfloridae, $21=$ Syngnathuslouisianae, $22=$ Syngnathus scovelli, 25=Lutjanus griseus, $30=$ Eucinostomus melanopterus, $34=$ Chaetodipterus faber, $35=$ Bairdiella chrysoura, $38=$ Cynoscion nebulosus, $41=$ Archosargus probatocephalus; December $=$ right: $6=$ Opsanus beta, $7=$ Eleotris pisonis, 8 = Ctenogobius boleosoma, $12=$ Gobiosoma robustum, $17=$ Achirus lineatus, $20=$ Syngnathus floridae, 21 = Syngnathus louisianae, 22 = Syngnathus scovelli, 26 = Lutjanus synagris, $28=$ Eucinostomus argenteus, 35 = Bairdiella chrysoura, 38 = Cynoscion nebulosus, $41=$ Archosargus probatocephalus, $42=$ Lagodon rhomboides . 
were present in the central and southern regions: Hypanus sabinus, Diapterus rhombeus, and Chaetodipterus faber. Eleven species (marked 4) were recorded only in the north, one species (Menticirrhus americanus, marked 5) only in the centre, and the other 14 species (marked 6) only in the south.

Temporal distribution. RENFRO: The fishes collected in August were more widely distributed (9 localities) and more species (16 spp.) were collected than in December ( 5 localities, 14 spp.) (Fig. 2, Table 2). OTTER TRAWL: The otter trawl collected more species than the Renfro and, as with the Renfro, the fish collected in August had a wider distribution (15 localities) than those of December (10 localities). However, fewer species were collected in August (20 spp.) than in December (25 spp.) (Fig. 3, Table 2).

Overall, the same number of species (28 spp.) was collected with the two nets in August and December, of which 14 were collected only in August, 14 only in December and 14 both months (Table 3 ).

Comparison of lagoons. The presence of the Laguna de Tamiahua fish species recorded by 26 other studies (the references are cited at the end of the Introduction section) in 14 other lagoons of the Mexican coast of the Gulf of Mexico (Términos, Mecoacán, Redonda, Machona, Carmen, Ostión, Sontecomapan, Alvarado, Mandinga, La Mancha, Chica-Grande, Tampamachoco, Pueblo Viejo, and Madre) was compiled together with the authors' unpublished data, all dating from the year 1991 to the present. Of the 170 species, five were recorded only in Laguna de Tamiahua and 10 were present in the 15 lagoons, while the other 145 species were present in 2 to 14 lagoons. The first group includes the species Mustelus canis, Atractosteus spatula, Coptodon rendalli, Peprilus triacanthus and Stenotomus chrysops, and the second group includes Hypanus sabinus, Cathorops melanopus, Achirus lineatus, Centropomus undecimalis, Lutjanus griseus, Diapterus auratus,

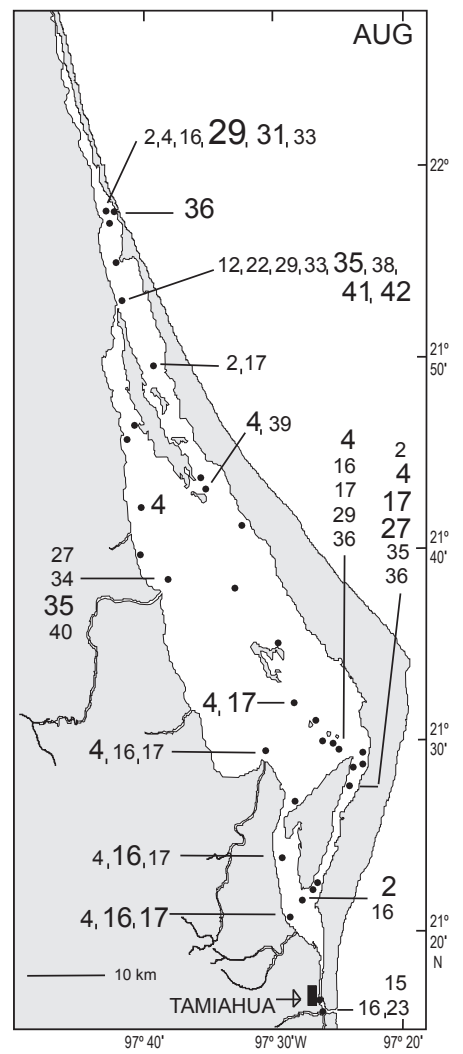

Fig. 3. Laguna de Tamiahua, Gulf of Mexico, Mexico-fish sampling in 1996 with an otter trawl; August = left, and December $=$ right: $1=$ Hypanus sabinus, $2=$ Ariopsis felis, $3=$ Bagre marinus, $4=$ Cathorops aguadulce, $5=$ Cathorops melanopus, $6=$ Opsanus beta, $7=$ Eleotris pisonis, $8=$ Ctenogobius boleosoma, $9=$ Gobionellus hastatus, 10 = Gobionellus oceanicus, 11 = Gobiosoma bosc, 12 = Gobiosoma robustum, 13 = Oreochromis mossambicus, 14 = Lucania parva, $15=$ Chloroscombrus chrysurus, $16=$ Citharichthys spilopterus, $17=$ Achirus lineatus, 18 = Symphurus civitatium, 19 = Hippocampus zosterae, 20 = Syngnathus floridae, 21 = Syngnathus louisianae, 22 = Syngnathus scovelli, 23 = Trichiurus lepturus, $24=$ Centropomus ensiferus, $25=$ Lutjanus griseus, $26=$ Lutjanus synagris, 27 = Diapterus rhombeus, $28=$ Eucinostomus argenteus, $29=$ Eucinostomus gula, $30=$ Eucinostomus melanopterus, 31 = Gerres cinereus, $32=$ Conodon nobilis, $33=$ Orthopristis chrysoptera, $34=$ Chaetodipterus faber, 35 = Bairdiella chrysoura, $36=$ Bairdiella ronchus, $37=$ Cynoscion arenarius, $38=$ Cynoscion nebulosus, $39=$ Cynoscion nothus, 40 = Menticirrhus americanus, 41 =Archosargus probatocephalus, 42 =Lagodon rhomboides; the three S's in the upper right hand corner of the map on the right represent the sizes of the species' numbers for the three density ranges 
D. rhombeus, Eucinostomus melanopterus, Bairdiella ronchus and Archosargus probatocephalus.

A cluster analysis based on the presence of fish species in the 15 Mexican lagoons of the Gulf of Mexico formed four clear groups. Group I with Carmen (76 spp.) and Machona (74 spp.), Group II with Tamiahua (170 spp.), Tampamachoco (139 spp.), Términos (127 spp.), Alvarado (117 spp.), and
Madre (109 spp.), Group III with Sontecomapan (90 spp.) and Mandinga (83 spp.) and Group IV with La Mancha (66 spp.) and Ostión (55 spp.). The lagoons Pueblo Viejo (83 spp.), Chica-Grande (49 spp.), Mecoacán (43 spp.), and Redonda (32 spp.) did not form part of any close group (Fig. 4).

Table 2

Fish species collected in August and December 1996 in three regions of the Laguna de Tamiahua, Gulf of Mexico, Mexico

\begin{tabular}{|c|c|c|c|c|c|c|c|c|c|c|c|c|c|}
\hline \multirow{2}{*}{ Species } & \multirow{2}{*}{ SDP } & \multicolumn{3}{|c|}{ Aug R } & \multicolumn{3}{|c|}{ Aug OT } & \multicolumn{3}{|c|}{ Dec R } & \multicolumn{3}{|c|}{ Dec OT } \\
\hline & & $\mathrm{N}$ & $\mathrm{C}$ & $\mathrm{S}$ & $\mathrm{N}$ & $\mathrm{C}$ & $\mathrm{S}$ & $\mathrm{N}$ & $\mathrm{C}$ & $\mathrm{S}$ & $\mathrm{N}$ & $\mathrm{C}$ & $\mathrm{S}$ \\
\hline Hypanus sabinus & 3 & & & & & & & & & & & $\mathrm{X}$ & $\mathrm{X}$ \\
\hline Ariopsis felis & 2 & & & & $\mathrm{X}$ & & $\mathrm{X}$ & & & & & & \\
\hline Bagre marinus & 6 & & & & & & & & & & & & $\mathrm{X}$ \\
\hline Cathorops aguadulce & 1 & & & & $\mathrm{X}$ & $\mathrm{X}$ & $\mathrm{X}$ & & & & & $\mathrm{X}$ & $\mathrm{X}$ \\
\hline Cathorops melanopus & 6 & & & & & & & & & & & & $\mathrm{X}$ \\
\hline Opsanus beta & 2 & $\mathrm{X}$ & & $\mathrm{X}$ & & & & $\mathrm{X}$ & & & $\mathrm{X}$ & & $\mathrm{X}$ \\
\hline Eleotris pisonis & 6 & & & & & & & & & $\mathrm{X}$ & & & \\
\hline Ctenogobius boleosoma & 6 & & & & & & & & & $\mathrm{X}$ & & & \\
\hline Gobionellus hastatus & 6 & & & & & & & & & & & & $\mathrm{X}$ \\
\hline Gobionellus oceanicus & 6 & & & & & & & & & & & & $\mathrm{X}$ \\
\hline Gobiosoma bosc & 6 & & & $\mathrm{X}$ & & & & & & & & & \\
\hline Gobiosoma robustum & 1 & $\mathrm{X}$ & $\mathrm{X}$ & $\mathrm{X}$ & $\mathrm{X}$ & & & $\mathrm{X}$ & & $X$ & $\mathrm{X}$ & & \\
\hline Oreochromis mossambicus & 4 & & & & & & & & & & $\mathrm{X}$ & & \\
\hline Lucania parva & 4 & $\mathrm{X}$ & & & & & & & & & & & \\
\hline Chloroscombrus chrysurus & 6 & & & & & & $X$ & & & & & & \\
\hline Citharichthys spilopterus & 1 & & & & $\mathrm{X}$ & $\mathrm{X}$ & $\mathrm{X}$ & & & & & & $\mathrm{X}$ \\
\hline Achirus lineatus & 1 & & & $\mathrm{X}$ & $\mathrm{X}$ & $\mathrm{X}$ & $\mathrm{X}$ & & $\mathrm{X}$ & & $\mathrm{X}$ & $\mathrm{X}$ & $\mathrm{X}$ \\
\hline Symphurus civitatium & 6 & & & & & & & & & & & & $\mathrm{X}$ \\
\hline Hippocampus zosterae & 2 & $\mathrm{X}$ & & $\mathrm{X}$ & & & & & & & & & \\
\hline Syngnathus floridae & 4 & $\mathrm{X}$ & & & & & & $\mathrm{X}$ & & & $X$ & & \\
\hline Syngnathus louisianae & 6 & & & $\mathrm{X}$ & & & & & & $\mathrm{X}$ & & & \\
\hline Syngnathus scovelli & 1 & $\mathrm{X}$ & $\mathrm{X}$ & $\mathrm{X}$ & $\mathrm{X}$ & & & $\mathrm{X}$ & & $\mathrm{X}$ & $\mathrm{X}$ & & \\
\hline Trichiurus lepturus & 6 & & & & & & $\mathrm{X}$ & & & & & & \\
\hline Centropomus ensiferus & 6 & & & & & & & & & & & & $\mathrm{X}$ \\
\hline Lutjanus griseus & 4 & $\mathrm{X}$ & & & & & & & & & & & \\
\hline Lutjanus synagris & 4 & & & & & & & $\mathrm{X}$ & & & $\mathrm{X}$ & & \\
\hline Diapterus rhombeus & 3 & & & & & $\mathrm{X}$ & $\mathrm{X}$ & & & & & & \\
\hline Eucinostomus argenteus & 4 & & & & & & & $\mathrm{X}$ & & & $\mathrm{X}$ & & \\
\hline Eucinostomus gula & 2 & & & & $\mathrm{X}$ & & $\mathrm{X}$ & & & & & & \\
\hline Eucinostomus melanopterus & 2 & $\mathrm{X}$ & & $\mathrm{X}$ & & & & & & & $\mathrm{X}$ & & \\
\hline Gerres cinereus & 4 & & & & $\mathrm{X}$ & & & & & & & & \\
\hline Conodon nobilis & 6 & & & & & & & & & & & & $\mathrm{X}$ \\
\hline Orthopristis chrysoptera & 4 & & & & $\mathrm{X}$ & & & & & & & & \\
\hline Chaetodipterus faber & 3 & & & $\mathrm{X}$ & & $\mathrm{X}$ & & & & & & & \\
\hline Bairdiella chrysoura & 1 & $\mathrm{X}$ & & & $\mathrm{X}$ & $\mathrm{X}$ & $\mathrm{X}$ & $\mathrm{X}$ & & & $\mathrm{X}$ & & $\mathrm{X}$ \\
\hline Bairdiella ronchus & 2 & & & & $\mathrm{X}$ & & $\mathrm{X}$ & & & & & & $\mathrm{X}$ \\
\hline Cynoscion arenarius & 6 & & & & & & & & & & & & $\mathrm{X}$ \\
\hline Cynoscion nebulosus & 1 & $\mathrm{X}$ & $\mathrm{X}$ & $\mathrm{X}$ & $\mathrm{X}$ & & & $\mathrm{X}$ & & & $\mathrm{X}$ & & \\
\hline Cynoscion nothus & 4 & & & & $\mathrm{X}$ & & & & & & & & \\
\hline Menticirrhus americanus & 5 & & & & & $\mathrm{X}$ & & & & & & & \\
\hline Archosargusprobatocephalus & 4 & $\mathrm{X}$ & & & $\mathrm{X}$ & & & $\mathrm{X}$ & & & $\mathrm{X}$ & & \\
\hline Lagodon rhomboides & 4 & & & & $\mathrm{X}$ & & & $\mathrm{X}$ & & & $\mathrm{X}$ & & \\
\hline Number of species & & 11 & 3 & 11 & 15 & 7 & 10 & 10 & 1 & 5 & 13 & 3 & 15 \\
\hline
\end{tabular}

$\mathrm{SDP}=$ spatial distribution pattern, $1=$ throughout the lagoon, $2=$ in the northern and southern regions, $3=$ in the central and southern regions, $4=$ only in the northern region, $5=$ only in the central region, $6=$ only in the southern region; Aug = August, Dec $=$ December, $\mathrm{R}$

$=$ Renfro beam net, $\mathrm{OT}=$ otter trawl; $\mathrm{N}=$ north, $\mathrm{C}=$ centre, $\mathrm{S}=$ south. 


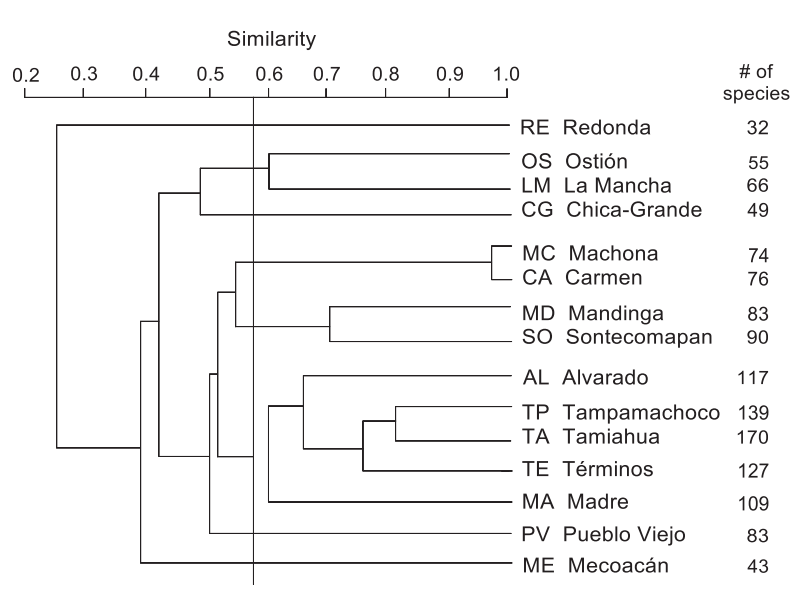

Fig. 4. Cluster of Mexican lagoons of the Gulf of Mexico based on fish species; vertical line (0.57) indicates the level of group recognition

\section{DISCUSSION}

Studies carried out on the fish of the Laguna de Tamiahua have recorded different numbers of species, with some species present in most studies and others in only a few. The difference in the number of recorded species reflects the variety of sampling methods used, the sampling intensity of each study, the seasons of the year when sampling took place and the prevailing environmental conditions during each study. In addition, some studies, such as that of CastroAguirre et al. (1999), are compilations. The numbers of fish species recorded for the lagoon since 1991 in the eight studies mentioned in the Results are presented in Table 4. The total number of species now compiled for the Laguna de Tamiahua is 170 species.

The 16 species of the family Sciaenidae collected in this study reflect the high species richness that is typical of this family in estuarine-lagoon systems. This family has been placed first among the stenohaline marine component and third among the euryhaline marine component of the dominant fish groups both in Mexico (Castro-Aguirre et al. 1999) and worldwide (Elliott et al. 2007, Franco et al. 2008). In addition, the five families with the majority of species collected in this study (Sciaenidae 16 spp., Gobiidae 12 spp., Carangidae 9 spp., Gerreidae 9 spp., and Clupeidae 7 spp.) coincide totally with Franco-López and Chavez-López (1993) who recorded only slightly less species for each (Sciaenidae 14 spp., Gerreidae 8 spp., Gobiidae 8 spp., Carangidae 7 spp., and Clupeidae 6 spp.). These small differences are due to the above-stated reasons, as well as to the fish population dynamics determined by natural and anthropogenic fluctuations (Pérez-Hernández and Torres-Orozco 2000). It is important to point out that even when a high number of species is recorded, it does not necessarily represent all the existing species, as it is almost impossible to record them all during field work.

Special status. The two species cited in the Norma Oficial Mexicana (Anonymous 2010) and the IUCN Red List of Threatened Species under special status are the broadspotted molly, Poecilia latipunctata, and the dwarf seahorse, Hippocampus zosterae. Poecilia latipunctata is a euryhaline species that lives in warm waters among submerged aquatic vegetation. This group of livebearers is important in the aquacultural industry and may be locally overfished, a situation that has gained it the special status of 'in danger of extinction' and 'critically endangered', apart from its limited distribution that establishes it as 'endemic to Mexico' (Contreras-Balderas and AlmadaVillela 1996). The stenohaline marine $H$. zosterae lives in seagrass beds. Its major threats are overfishing for the aquarium trade and habitat loss (Waycott et al. 2009, Short et al. 2011). However, the IUCN Red List of Threatened Species considers its populations to be stable and classifies it as 'under special protection' in Mexico and 'of least concern' in general (Masonjones et al. 2017).

Capture seasonality of fish species collected in 1996

Table 3

in the Laguna de Tamiahua, Gulf of Mexico, Mexico

\begin{tabular}{lll}
\hline & \multicolumn{1}{c}{ Fish captured in } \\
\hline \multicolumn{1}{c}{ August } & \multicolumn{1}{c}{ December } & \multicolumn{1}{c}{ Both months } \\
\hline Ariopsis felis & Hypanus sabinus & Cathorops aguadulce \\
Gobiosoma bosc & Bagre marinus & Opsanus beta \\
Lucania parva & Cathorops melanopus & Gobiosoma robustum \\
Chloroscombrus chrysurus & Eleotris pisonis & Citharichthys spilopterus \\
Hippocampus zosterae & Ctenogobius boleosoma & Achirus lineatus \\
Trichiurus lepturus & Gobionellus hastatus & Syngnathus floridae \\
Lutjanus griseus & Gobionellus oceanicus & Syngnathus louisianae \\
Diapterus rhombeus & Oreochromis mossambicus & Syngnathus scovelli \\
Eucinostomus gula & Symphurus civitatium & Eucinostomus melanopterus \\
Gerres cinereus & Centropomus ensiferus & Bairdiella chrysoura \\
Orthopristis chrysoptera & Lutjanus synagris & Bairdiella ronchus \\
Chaetodipterus faber & Eucinostomus argenteus & Cynoscion nebulosus \\
Cynoscion nothus & Conodon nobilis & Archosargus probatocephalus \\
Menticirrhus americanus & Cynoscion arenarius & Lagodon rhomboides \\
\hline
\end{tabular}


Table 4 fish species including Mugil cephalus, M. curema,

Number of fish species recorded for the Laguna de Tamiahua, Gulf of Mexico, Mexico from 1991 to the presently reported study

\begin{tabular}{lcc}
\hline \multicolumn{1}{c}{ Reference } & Year & $\begin{array}{c}\text { No. of } \\
\text { species }\end{array}$ \\
\hline Reséndez-Medina and Kobelkowsky-Díaz & 1991 & 105 \\
Franco-López and Chavez-López & 1993 & 112 \\
This study & 1996 & 42 \\
Castro-Aguirre et al. & 1999 & 106 \\
Díaz-Ruiz et al. & 2003 & 83 \\
Gaspar-Dillanes and Barba-Torres & 2004 & 84 \\
Sanvicente-Añorve et al. & 2011 & 32 \\
Abarca-Arenas et al. & 2012 & 143 \\
Ocaña-Luna and Sánchez-Ramírez & 2016 & 40 \\
\hline Total recorded in the presently reported study & 2018 & $\mathbf{1 7 0}$ \\
\hline
\end{tabular}

New records. Four species are first records for the Laguna de Tamiahua. The collection of only two specimens of the offshore tonguefish, Symphurus civitatium, in Ensenada Grande (Fig. 3) may respond to the fact that this demersal species can be taken as bycatch by shrimp trawling (Munroe 2015), an activity that is intensive in this area of the lagoon and may adversely affect its populations. The presence of this species in the lagoon is justified by its preference for warm waters, as was observed by Munroe et al. (2000) who recorded an abundance of $82 \%$ in Barataria Bay, Louisiana and of only $2 \%$ in North Carolina, USA. The limited presence of the following three species in the Laguna de Tamiahua responds to their particular characteristics, such that the Mayan sea catfish, Ariopsis assimilis, is more common in the Caribbean than in the Gulf of Mexico (Marceniuk and Menezes 2007), the euryhaline lebranche mullet, Mugil liza, undergoes trophic migrations along the coasts (Thomson 1978) and the eurytopic orange filefish, Aluterus schoepfii, is more common on continental shelves (Matsuura et al. 2015, Borgo unpublished*).

Commercial importance. Regarding the commercially important species in the Laguna de Tamiahua, different reports provide different data, although most coincide for the most part. The Diario Oficial de la Federación (Anonymous 2014) reported approximately 30 commercially important fish species in the lagoon, among which the 10 most important in terms of value and volume are the white mullet, Mugil curema (45\%), the sand weakfish, Cynoscion arenarius, and the spotted weakfish, C. nebulosus (25\% each), the Irish mojarra, Diapterus auratus, the striped mojarra, Eugerres plumieri, and the sheepshead, Archosargus probatocephalus ( $8 \%$ each), the striped mullet, M. cephalus (5\%), the Atlantic croaker, Micropogonias undulatus (4\%), the common snook, Centropomus undecimalis (3\%), and the fat snook C. parallelus (1\%). The Carta Nacional Pesquera (Anonymous 2012a) reported 31 commercially important
C.parallelus, the Mexican snook, C.poeyi, C. undecimalis, the mutton snapper, Lutjanus analis, the schoolmaster snapper, L. apodus, the northern red snapper, L. campechanus, the cubera snapper, L. cyanopterus, the grey snapper, L. griseus, the lane snapper, L. synagris, Cynoscion arenarius, C. nebulosus, and the silver seatrout, C. nothus, together with information on capture volume per state, recommended management strategies, fishing effort, reference points and status per species. FrancoLópez and Chavez-López (1993) listed M. cephalus, M. curema, Centropomus undecimalis, the silver perch, Bairdiella chrysoura, Cynoscion nebulosus, and Archosargus probatocephalus as important lagoon fisheries. Of all these species, L. griseus, L. synagris, B. chrysoura, C. arenarius, C. nebulosus, C. nothus, and A. probatocephalus were collected in this study. Of the 10 most important fishery species stated above for Tamiahua, two have been reported as important in the Laguna Madre, Tamaulipas (Raz-Guzmán and Huidobro 2002), nine in the Laguna de Alvarado, Veracruz (Carrillo-Alejandro et al. 2014b) and nine in the Laguna de Términos, Campeche (Ayala-Pérez et al. 2015). These locally fished species provide a high-value food source for humans and form an important part of the economy of the fishermen of the region. Apart from the commercially important species, small fish with no market value, such as the Jenny mojarra, Eucinostomus gula, are used as bait or to prepare fish flour. Mugil curema and M. cephalus sustain relatively important subsistence and small-scale fisheries. Both are regulated by annual seasonal closures off Tamaulipas and Veracruz from December to February. Minimum catch sizes are $26 \mathrm{~cm}$ for $M$. curema and $31 \mathrm{~cm}$ for M. cephalus, and minimum mesh sizes are $76 \mathrm{~mm}$ for M. curema and $101 \mathrm{~mm}$ for M. cephalus. Mugil curema is the main source of income for the Laguna de Tamiahua fishermen (Ibáñez Aguirre and Lleonart 1996). Since catches have declined over the past years, it is recommended that the current fishing effort not increases in terms of fishing permits and exploitation levels of $M$. cephalus not exceed $4665 \mathrm{t}$ per year in Veracruz. It is also recommended that a management plan for the Tamaulipas-North Veracruz fishing region should be developed (Anonymous 2012b), as well as the preservation of estuaries and mangroves on which both species depend for spawning and juvenile habitats. Cynoscion nebulosus, $C$. arenarius, and $C$. nothus sustain the economically valuable Mexican seatrout fishery. The first species represents $60 \%$ of the total catch, most of it off Veracruz, while in Tamaulipas $86 \%$ of the catch takes place in the Laguna Madre. Landings have fluctuated over the years, however, there is no evidence of a significant population decline and there are no known major threats. No official management measures exist in Mexico for these species, but recommendations include a maximum catch of $5055 \mathrm{t}$, not increasing fishing effort, implementing regulations such as permit giving, recording species- 
specific catch data, restricting gillnet length to $12.7 \mathrm{~m}$, mesh size to $7.6 \mathrm{~cm}$ and minimum specimen size to $30 \mathrm{~cm}$ total length, and developing a fishery management plan for the Tamaulipas-North Veracruz fishing region (Anonymous 2012b). Snook species are valued highly due to their good flavour. Centropomus undecimalis is fished in Tamaulipas, Veracruz, and Campeche, while C. poeyi is fished mostly in Veracruz. Both are at a level of maximum sustainability and fishing effort should not be increased (Anonymous 2012b), particularly $C$. undecimalis as it matures late, is long-lived and may, therefore, be easily overfished. Centropomus parallelus is fished in Tamaulipas, Veracruz, Tabasco, and Campeche (RazGuzmán and Huidobro 2002). Seasonal fishery closures for $C$. undecimalis and C. poeyi are 15 May-30 June from Soto la Marina, Tamaulipas to Chachalacas, Veracruz and July 1-August 15 from Chachalacas to Tonalá, Veracruz. There are no snook fishery regulations for Tabasco and Campeche, however, it is recommended that annual average catches not exceed $2300 \mathrm{t}$ in Tabasco, $2100 \mathrm{t}$ in Campeche, $1500 \mathrm{t}$ in Veracruz, and $100 \mathrm{t}$ in Tamaulipas and Yucatán. It is further recommended to establish a minimum catch size, to require disclosure of official catches of each species, to design recovery strategies through analyses and assessments each fishing season, and to implement specific management plans (Anonymous 2012b). Snappers are widely distributed and abundant species. Lutjanus campechanus is part of a highly valued multi-species fishery in Mexico. It represents $90 \%$ of lutjanid landings. It is valuable in both domestic and international markets, with most $(74 \%-87 \%)$ of the landings exported. Overfishing is assumed to be occurring, together with bycatch of juveniles, by shrimp trawlers. In general, landings decreased by $58 \%$ from $7205 \mathrm{t}$ (1993) to $3021 \mathrm{t}$ (2013), and fishing effort has increased since 1990 off Tabasco - the area known for highest landings of Lutjanus campechanus in the Gulf of Mexico. Access to the commercial snapper fishery is now controlled through permits and gear restrictions. Management recommendations call for a decrease of $30 \%$ in fishing effort off Veracruz, Campeche, and Yucatán, and a reduced sale of permits for Tamaulipas, Tabasco, and Quintana Roo. It is also recommended to introduce the use of bycatch reduction devices in shrimp trawlers, to issue specific permits for this species, to evaluate the effectiveness of these measures and to establish benchmarks for management plans (Anonymous 2012b). Four species are taken as bycatch in the Lutjanus campechanus fishery, the juveniles of these species are taken as bycatch by shrimp trawlers (Anonymous 2012b), and their spawning aggregations are targeted by fishermen, making them especially vulnerable to overfishing. These are Lutjanus analis, a highly priced species, L. synagris, of which landings decreased by $95 \%$ from $2745 \mathrm{t}$ (1993) to $142 \mathrm{t}$ (2013) (Anonymous 2015a), L. griseus, with average landings of 214 t (2005-2011) (Lindeman et al. 2016a), and L. cyanopterus, the largest snapper (160 cm maximum length, Allen 1985) of which small adults may be locally important but larger specimens are commonly avoided, especially where they are ciguatoxic (Lindeman et al. 2016b). Lutjanus apodus is not commonly targeted directly, but is caught locally and data on landings are largely unavailable (Lindeman et al. 2016c). Regarding the other species, stable catches of $A$. probatocephalus were reported from 2002 to 2011 (Carpenter et al. 2014). The following four species are also taken as bycatch by shrimp fisheries: Diapterus auratus is of minor commercial importance (Fraser and Gilmore 2015a), Eugerres plumieri is fished mostly in Chetumal Bay, Quintana Roo (Aguirre-Macedo et al. 2007) and Celestún, Yucatán (Poot-Salazar et al. 2009), for Micropogonias undulatus it is recommended that fisheries regulations be established and that estuarine nursery habitats be protected against pollution and coastal development (Chao and EspinosaPerez 2015a), and B. chrysoura is used mostly as bait, though larger specimens are marketed locally (Chao and Espinosa-Perez 2015b).

Density. A comparison of density values between those recorded here and those reported in other studies is practically impossible due to the variety of sampling gear used and numerical analyses applied. An example of this is the wide range of values from the much lower densities recorded by Díaz-Ruíz et al. (2000) for the chain pipefish, Syngnathus louisianae $\left(0.0163\right.$ ind $\left.\cdot \mathrm{m}^{-2}\right)$, and the gulf pipefish, S. scovelli $\left(0.0169\right.$ ind $\left.\cdot \mathrm{m}^{-2}\right)$, in the Laguna de Tamiahua using a $60 \mathrm{~m}$ long beach seine net, to the much larger maximum density recorded by Barba Macías (1999) for the silver mojarra, Eucinostomus argenteus (26.2 ind $\cdot \mathrm{m}^{-2}$ ), in the Laguna Madre, Tamaulipas using a Renfro beam net. In addition, fluctuations in density, distribution, and species richness have been observed in the majority of coastal lagoons in response to community dynamics (Aguirre-León et al. 2014). This is also the case in this study, as the greater density values were recorded for the larger specimens that were collected in August with the otter trawl (see Table 1), indicating that these species were recruited during the summer after the August spawning, as was observed by Ocaña-Luna and Sánchez-Ramírez (2016). Other factors that may influence the success of a species, and thus its density, include its use of the habitat, its feeding habits, and its geographic distribution. Considering the habitat, Cathorops aguadulce is a freshwater and brackish species. Citharichthys spilopterus, Achirus lineatus, S. scovelli, Diapterus rhombeus, E. gula, E. melanopterus, and Bairdiella chrysoura are common in seagrass beds in shallow estuaries and lagoons. Opsanus beta, Gobiosoma robustum, and Cynoscion nebulosus live in seagrass beds, reefs, oyster banks, and jetties in estuarine and coastal waters. Considering feeding habits, $O$. beta is a euryhaline cryptic, sedentary, opportunistic, and voracious carnivore (Rodger and von Zharen 2012), while $C$. nebulosus is an opportunistic carnivore (Blanchet et al. 2001) that uses an ambush predatory strategy and selects the largest fish, such as mullet, it can possibly catch and swallow. The habitats used by these high-density species are common in estuarine systems, including the Laguna de Tamiahua. This use of the habitat, together with the species' successful feeding habits, favours their 
presence in high numbers in these areas. Regarding geographic distribution, the high-density species of the Laguna de Tamiahua have wide and almost similar ranges throughout the Mexican lagoons of the Gulf of Mexico. The distribution of these species spans from the Laguna Madre, Tamaulipas south to different points: Cathorops aguadulce and Citharichthys spilopterus to the Laguna de Términos, Campeche, S. scovelli to Champotón, Campeche and $O$. beta, G. robustum, Achirus lineatus, D. rhombeus, E. gula, E. melanopterus, B. chrysoura, and Cynoscion nebulosus to Celestún, Yucatán (Raz-Guzmán and Huidobro 2002, Gaspar-Dillanes and Barba-Torres 2004, Ayala-Pérez et al. 2014). These wide distributions in the Gulf of Mexico are a measure of the species' success in their estuarine communities.

Dominance. Three species collected with the otter trawl presented the highest density and spatial frequency values: the dark sea catfish, Cathorops melanopus (in December), the bay whiff, Citharichthys spilopterus (both months), and Eucinostomus gula (in August). Cathorops melanopus is a euryhaline species with a high level of morphological, feeding, reproductive, and migratory adaptability that allows it to live in many habitats, including seagrass beds, sand and mud in estuarine systems, and ensures the success of its populations (Ayala-Pérez et al. 2008). As a result of this, it has been recorded as dominant in other Mexican lagoons of the Gulf of Mexico such as the Laguna de Términos, Campeche (Ayala-Pérez et al. 2003), and the Laguna La Mancha (Pérez 2007), Laguna Chica-Grande (Aguirre-León et al. 2014), and Laguna Pueblo Viejo (Castillo-Rivera et al. 2005) in Veracruz. Citharichthys spilopterus is an abundant, widespread species found on muddy substrates, in mangroves and in shallow tropical estuarine, hypersaline, and marine waters. It is one of the most common flatfishes in the Gulf of Mexico and is a dominant species in the Laguna de Términos, Campeche (Ayala-Pérez et al. 2003), and Laguna Chica-Grande, Veracruz (Pérez 2007). Eucinostomus gula, for which the greatest density was recorded (14.33 ind $\cdot \mathrm{min}^{-1}$ west of Boca de Tampachichi), is a common, widely distributed, and abundant species in seagrass beds, mangroves, and sandy substrates. It is abundant in Ría Lagartos, Yucatán (Peralta-Meixueiro and Vega-Cendejas 2011), the Reserva de la Biósfera Los Petenes (Ayala-Pérez et al. 2014), Río Champotón (López-López et al. 2009), and the Laguna de Términos (Ayala-Pérez et al. 2003) in Campeche, and the Laguna Madre, Tamaulipas (Raz-Guzmán and Huidobro 2002), to name a few. Apart from the dominant species, the Olmstead-Tükey test identified the Atlantic stingray, Hypanus sabinus (otter trawl, December), and Hippocampus zosterae (Renfro, August) as low densityspatially frequent species. Hypanus sabinus, a permanent estuarine species, was collected north of Boca de Corazones $\left(0.99\right.$ ind $\left.\cdot \min ^{-1}\right)$, which agrees with its preference for shallow sandy substrates (Bigelow and Schroeder 1953) in freshwater, brackish, and marine environments. For Hippocampus zosterae, low-density values have been previously recorded as, for example, the 0.02 to 0.18 ind $\cdot \mathrm{m}^{-2}$ reported by Masonjones et al. (2010) for Tampa
Bay, Florida, a range of values that includes our datum $\left(0.06\right.$ ind $\left.\cdot \mathrm{m}^{-2}\right)$. These low densities are strongly related to the sampling method and gear used. Due to their small size, cryptic habit, and ability to hold on to a substrate, traditional collection methods rarely obtain seahorses and, thus, catch rates vary independently of actual population size (Masonjones et al. 2017). This species was collected along 'costa mar', which agrees with its ecotic position as a small seagrass bed-dwelling stenohaline marine species. The caitipa mojarra, Diapterus rhombeus, with a high density of 7.99 ind $\cdot \mathrm{min}^{-1}$ (otter trawl, August) and a low spatial frequency of two localities (loc\#5, loc\#29; Fig. 3 ), is a common, widely distributed, euryhaline species that lives in shallow tropical freshwater, brackish, and hypersaline systems, mangroves and vegetated sandy and muddy substrates. It is a dominant species in the Laguna de Términos, Campeche (Ayala-Pérez et al. 2003), Laguna La Mancha (Pérez 2007) and Laguna Chica-Grande (Aguirre-León et al. 2014) in Veracruz, Guadeloupe, French Antilles (Bouchereau et al. 2012) and off Rio de Janeiro, Brazil (Pessanha and Araújo 2014).

Ecotic position. Of the species collected in this study (see Table 1), the marine component was dominant with $88.1 \%$ (37 spp.) of the species, a greater percentage than the $70 \%$ of Franco-López and Chavez-López (1993) and closer to the $90 \%$ of Ocaña-Luna and Sánchez-Ramírez (2016). The role that marine species play in the ecological organisation of coastal lagoons is important, as juveniles and adults migrate from the sea in search of food, profit from the high secondary production and protection provided by estuarine habitats (Raz-Guzmán and Sánchez 1996a, Sánchez et al. 1996), and constitute a rich fishery resource for the local residents. Among these marine species, the euryhaline component $(73.8 \%, 31 \mathrm{spp}$.) includes species that tolerate marked changes in salinity and enter lagoons in response to the relative abundance of food and protection they find, or for reasons unrelated to feeding or reproduction (Castro-Aguirre et al. 1999). This percentage is slightly greater than that of $69 \%$ recorded by Gaspar-Dillanes and Barba-Torres (2004) for the Laguna de Tamiahua and that of $70.2 \%$ recorded by Raz-Guzmán and Huidobro (2002) for the Laguna Madre, Tamaulipas. In contrast, the stenohaline component $(14.3 \%, 6$ spp.) includes occasional visitors to coastal lagoons to the areas where, and at the times when, salinity conditions are adequate. However, their presence may also be accidental (Castro-Aguirre et al. 1999). This percentage is similar to the $15.5 \%$ recorded by Gaspar-Dillanes and Barba-Torres (2004) for the Laguna de Tamiahua and lower than the $22.6 \%$ recorded by RazGuzmán and Huidobro (2002) for the Laguna Madre. The permanent estuarine component $(9.5 \%, 4 \mathrm{spp}$.) groups species with a well developed osmoregulating mechanism that allows them to live permanently in environments with marked changes in salinity such as estuarine systems. Of the species collected by Gaspar-Dillanes and Barba-Torres (2004) in the Laguna de Tamiahua, 9.5\% were permanent, coinciding totally with the percentage obtained in this study. Of those collected by Franco-López and Chavez-López (1993) also in this lagoon, only $6 \%$ were permanent, while 
of the fish collected by Raz-Guzmán and Huidobro (2002) in the Laguna Madre, $7.1 \%$ were permanent estuarine species. The record of only one freshwater species $(2.4 \%$, the Mozambique tilapia, Oreochromis mossambicus) just inside the northern inlet of Boca de Tampachichi (Fig. 3 , salinity $32 \%$ ) reflects its capacity to tolerate brackish and marine environments (Cambray and Swartz 2007), particularly since its previous records in the lagoon have been for lower-salinity areas (Díaz-Ruiz et al. 2003, Gaspar-Dillanes and Barba-Torres 2004, Abarca-Arenas et al. 2012). This species has been widely introduced from south-eastern Africa to many localities worldwide for aquaculture and fisheries due to its excellent palatability (de Moor and Bruton 1988), as well as for the aquarium trade, sport fishing, and the biological control of nuisance plants and animals (Trewavas 1982). It can be reared under hypersaline conditions (Lamboj 2004), it tolerates low dissolved oxygen levels (de Moor and Bruton 1988), it is omnivorous and has a variety of feeding habits (Maitipe and De Silva 1985), its fecundity is high (Gupta and Acosta 2004) and it is aggressive towards other species (Bardach et al. 1972), all of which has enabled it to outcompete local species (Kottelat and Whitten 1996) in many countries. In the case of the Laguna de Tamiahua, no effect has been recorded due to its low abundance.

Spatial distribution. The majority of the species collected with the Renfro beam net were those with small specimens and low-density values. These were collected from seagrass beds along 'costa mar', mostly just inside Boca de Tampachichi, north of Isla Juan A. Ramírez and north of Isla del Idolo (see Fig. 2). These three localities had a greater presence of fish species as the nearby inlets favour immigration from the sea for the mostly euryhaline marine species recorded for this lagoon. 'Costa mar' is characterised by clear water with temperatures of $29.5-$ $34^{\circ} \mathrm{C}$ in August and $25.5-27^{\circ} \mathrm{C}$ in December, salinities of 24\%-38\% in August and 27\%o-30\% in December, Halodule wrightii seagrass beds and some macroalgae. The distribution of seagrass beds in the Mexican lagoons of the Gulf of Mexico is regulated by salinity, turbidity, and type of substrate (Raz-Guzmán and Barba 2000). The environmental heterogeneity and complexity in the Laguna de Tamiahua favour the availability of different habitats for fish with different feeding strategies. Previous studies have established the ecological relation between species and habitat, showing that complex habitats harbour a high infaunal and epifaunal biodiversity (Edgar et al. 1994, Boström and Bonsdorff 2000) and recognising the part that submerged aquatic vegetation plays in the recruitment of many invertebrates and fish in coastal lagoons (Heck and Crowder 1991). Typical of the smaller fish species is their distribution associated with seagrass beds where they find ideal habitats a nursery, feeding, and protection areas, as Heck and Crowder (1991), RazGuzmán and Sánchez (1996a), Sánchez et al. (1996), and Boström and Bonsdorff (2000) have recorded for benthic communities. Examples of these small species are Syngnathus louisianae and S. scovelli (see Díaz-Ruíz et al. 2000, Peralta-Meixueiro and Vega-Cendejas 2011).
Other slightly larger species like the flagfin mojarra, Eucinostomus melanopterus and Cynoscion nebulosus use these habitats mainly as feeding areas after entering the lagoon during the dry season when salinity increases (Franco-López and Chavez-López 1993). The otter trawl collected more species (35 spp.) than the Renfro (21 spp.), mostly of larger sizes, throughout the lagoon, though predominantly along 'costa tierra' and north of Isla Juan A. Ramírez, west of Boca de Tampachichi, north and west of Isla del Idolo and just inside Boca de Corazones (see Fig. 3). 'Costa tierra' is characterised by turbid water with temperatures of $28-33^{\circ} \mathrm{C}$ in August and $24-25.5^{\circ} \mathrm{C}$ in December, salinities of $24 \% 0-35 \%$ in August and 28\%o-30\% in December, some H. wrightii and much macroalgae, where larger fish that depend less on seagrass habitats may move freely. The inlets of the lagoon and adjacent areas favour fish migration to the lagoon and out to sea, a recurring pattern that has been reported for estuarine-lagoon systems (Harrison and Whitfield 2006). In short, the analysis of the spatial distribution of the fish collected in the Laguna de Tamiahua indicated that the majority of species favoured the margins of the islands Juan A. Ramírez and del Idolo (see Fig. 1), some areas off the streams and particularly 'costa mar' where seagrass beds provide ideal habitats, as has been recorded for many other lagoons. The species concentrated in the northern (24 spp.) and southern (30 spp.) regions of the lagoon, with less species in the central region (11 spp.), confirming the importance of the lagoon inlets as immigration routes for the visiting euryhaline marine species that take advantage of the environmental services the lagoon has to offer.

Temporal distribution. A review of the literature provided a wide variety of temporal distributions for the species collected in this study. Of the papers consulted, only two coincided with some species/seasons observed here: Ocaña-Luna and Sánchez-Ramírez (2016) recorded Gobiosoma bosc and Diapterus rhombeus in August, Gobionellus oceanicus and Cynoscion arenarius in November and Achirus lineatus both seasons, and DíazRuiz et al. (2003) recorded Eucinostomus gula and Orthopristis chrysoptera in August and E. argenteus in December. It is thus nearly impossible to establish patterns, and this reflects the species' freedom of movement in and out of coastal lagoons. However, the spatial distribution of the species was wider in August (Renfro 9 localities, otter trawl 15 localities, Figs. 2 and 3) than in December (Renfro 5 localities, otter trawl 10 localities, Figs. 2 and 3), in agreement with higher densities recorded in August (see Table 1). Somewhat similar data were found by Ocaña-Luna and Sánchez-Ramírez (2016), with more Anchoa mitchilli and Cetengraulis edentulus eggs and more A. mitchilli, Ctenogobius boleosoma, Lupinoblennius nicholsi, and Membras martinica larvae during the warm summer season. Díaz-Ruiz et al. (2003) also observed a greater abundance during the August rainy season, when fish take advantage of the nutrients provided by the increased up-river primary production of summer, and recorded a similar situation for the Laguna de Términos, Campeche. While marked environmental 
differences have been observed in many coastal lagoons in response to abiotic factors (Aguirre-León et al. 2014), the salinity values in the Laguna de Tamiahua overlapped across seasons (August 22\%o-38\%o, December 27\%o$32 \%$ ) and only the water temperature was clearly different (August $28-34^{\circ} \mathrm{C}$, December $24-27^{\circ} \mathrm{C}$ ). Water temperature regulates other parameters like salinity, stratification, and nutrient solubility, which, in turn, affect physiological processes like growth, reproduction, and migration and, thus, the distribution of species in ecosystems and the structure, composition, and organisation of estuarine communities. In general, fish communities tend to remain stable in coastal lagoons, and this is the case in the Laguna de Tamiahua where the majority of the species are eurythermal and euryhaline.

Comparison of lagoons. Of the 170 species recorded for the Laguna de Tamiahua, 10 were present in all the 15 Mexican lagoons of the Gulf of Mexico. Zoogeographically, eight of these 10 species are eurytopic. Six of these species have their southern limit in Brazil and for each, the northern limit is the following: Nova Scotia for Archosargus probatocephalus (see Robins and Ray 1986), Massachusetts for Lutjanus griseus (see Lindeman et al. 2016a), Chesapeake Bay for Hypanus sabinus (see Bigelow and Schroeder 1953), North Carolina for both Diapterus auratus (see MacossayCortéz et al. 2011) and Centropomus undecimalis (see Robins and Ray 1986), and Florida for D. rhombeus (see McEachran and Fechhelm 2005). The distribution of the other two species reaches further south. These are Achirus lineatus from South Carolina to north Argentina (Munroe 2002) and Eucinostomus melanopterus from Florida to Uruguay (Fraser and Gilmore 2015b). In addition, these eight species are found throughout the Gulf of Mexico and the Caribbean (Gaspar-Dillanes and Barba-Torres 2004). Cathorops melanopus and Bairdiella ronchus are warm water species previously reported, the first from Tamaulipas to Honduras and the second from Tamaulipas through the Caribbean to Brazil (Gaspar-Dillanes and Barba-Torres 2004). Regarding the habitat, nine species are euryhaline marine and $H$. sabinus is a permanent estuarine species, the 10 species are common and abundant in estuaries and lagoons, and most live on seagrass beds and sandy and muddy sediment (Raz-Guzmán and Huidobro 2002, Gaspar-Dillanes and Barba-Torres 2004), habitats that are widespread in the Laguna de Tamiahua. In contrast with these last 10 species, five species were recorded only for the Laguna de Tamiahua. These were previously reported by other authors: Mustelus canis by Castro-Aguirre et al. (1999), Atractosteus spatula by Reséndez-Medina and Kobelkowsky-Díaz (1991), Franco-López and ChavezLópez (1993), and Abarca-Arenas et al. (2012), Coptodon rendalli by Díaz-Ruiz et al. (2003), Peprilus triacanthus by Reséndez-Medina and Kobelkowsky-Díaz (1991) and Abarca-Arenas et al. (2012), and Stenotomus chrysops by Reséndez-Medina and Kobelkowsky-Díaz (1991) and Franco-López and Chavez-López (1993). In order to explain their presence in the Laguna de Tamiahua, one may consider their zoogeographic distribution and habitat preferences. The dusky smooth-hound, M. canis, ranges from Canada (Scott and Scott 1988) down the coast to Florida, the northern and western Gulf of Mexico, the Caribbean, Venezuela, southern Brazil, Uruguay, and northern Argentina, and is found mainly in inshore waters on the continental shelves (Compagno 1984). Bigelow and Schroeder (1948) stated that there might be several discrete populations of this demersal shark, separated by large geographical areas, with little movement between populations. The scup, S. chrysops ranges from Nova Scotia to Florida (Steimle et al. 1999), and the Gulf of Mexico from Florida to Texas (Robins and Ray 1986). The adults live on the continental shelf, around piers, rocks, and mussel beds (Terceiro 2012), while the juveniles live in shallow estuaries. Its record in the Laguna de Tamiahua extends its lower limit of geographic distribution south from Texas to Veracruz. This migration south may respond to larval dispersion on the shallow coastal current that flows from Louisiana and Texas to Campeche during the winter and back during the summer (Zavala-Hidalgo et al. 2003). The Atlantic butterfish, P. triacanthus, is distributed from Labrador (Coad and Reist 2004) to western Florida in the Gulf of Mexico (Vergara 1978). It is a common species in sandy estuaries and continental shelves (Smith 1997). With its presence in the Laguna de Tamiahua, its geographic distribution now includes the western Gulf of Mexico, to where the species may have arrived through larval dispersion and adult migrations on coastal currents, as is mentioned above for $S$. chrysops (see Zavala-Hidalgo et al. 2003), travelling west and south to the CarolineanTemperate and Caribbean-Tropical boundary at Cabo Rojo, on the island barrier of the Laguna de Tamiahua (Thurman 1987). The alligator gar, A. spatula, is found in the Mississippi River basin, south-western Ohio, southern Illinois, and the Gulf of Mexico coastal plain from Florida to Veracruz (Froese and Pauly 2018). It lives in large slow moving rivers, swamps, estuaries (Page and Burr 1991), and occasionally seawater. It is classified as rare, threatened, and endangered*. The redbreast tilapia, $C$. rendalli, is known from several places in the lower half of Africa. From there, it has been introduced elsewhere, usually for weed control and aquaculture, after which several countries have reported adverse ecological impacts. In Mexico, it is recorded for several rivers and dams in the states of Sinaloa, Jalisco, Michoacán, Oaxaca, Chiapas, Hidalgo, Veracruz, and Tabasco. It lives in quiet rivers, floodplains, and swamps. The presence of these five species in the Laguna de Tamiahua, and not in the other Mexican lagoons of the Gulf of Mexico, may respond to a low abundance, their appearance at times when no sampling was taking place (as at night), or a preference for habitats other than a typical coastal lagoon (rivers, floodplains, continental shelves).

The cluster analysis of the Laguna de Tamiahua fish species that are present in the 15 Mexican lagoons of the 
Gulf of Mexico formed groups of similar lagoons with respect to the presence of species. The lagoon most similar to the Laguna de Tamiahua (170 spp.) is Tampamachoco (with 139 shared species), and is followed by Términos (with 127 spp.), Alvarado (117 spp.), and Madre (109 spp.). Tamiahua, Tampamachoco, Términos, and Madre present a degree of environmental heterogeneity and complexity generated by seagrass beds and macroalgae (and mangroves in the first three), different sediment types and salinity gradients, all of which provide a rich variety of habitats (Sánchez and Raz-Guzmán 1997, Tunnell and Judd 2002) and favour the immigration and recruitment of the many euryhaline marine fish species. In addition, these lagoons are grouped as they are the most studied and have higher numbers of recorded fish species. A similar species richness has been reported for these lagoons for fish (Ocaña-Luna and Sánchez-Ramírez 2016), as well as for crustaceans (Raz-Guzmán and Sánchez 1998, Cid and Raz-Guzmán 2011, Raz-Guzmán and Soto 2017). The lagoons that share less than half of the Tamiahua species, except for Sontecomapan (90 spp.), are Mandinga (83 spp.), Carmen (76 spp.), Machona (74 spp.), La Mancha (66 spp.), and Ostión (55 spp.). The lagoons that are the least similar to the Laguna de Tamiahua in the cluster are Pueblo Viejo (83 spp.), Chica-Grande (49 spp.), Mecoacán (43 spp.), and Redonda (32 spp.). This is a reflection of their environmental characteristics among which are a low salinity and few seagrass habitats, as well as having been less studied. An obvious recommendation is to increase the number of studies on these last lagoons in order to fill gaps of information on the ichthyofauna.

Concluding, this study increases knowledge on the Laguna de Tamiahua, an ecologically and economically important RAMSAR site that sustains local and regional fisheries of shrimp, swimming crabs, oysters, and fish, on which local communities depend for a high-value food source and an important part of their economy. Data on the distribution of the fish species collected in the lagoon indicates that most species are found along the area locally called 'costa mar' where seagrass beds provide ideal habitats, near the islands Juan A. Ramírez and del Idolo, and near the northern and southern inlets of the lagoon. Of the 170 fish species (collected and compiled from the literature) of the Laguna de Tamiahua, 10 are eurytopic and were present in the 15 lagoons included in the list, while five species were recorded only in Tamiahua. A comparison among lagoons identified Chica-Grande, Mecoacán, and Redonda as having the smaller number of species and requiring more studies.

Taxonomic studies and inventories of fish species contribute to the knowledge of natural resources in estuaries and lagoons. They also support basic research that makes it possible to design ecological models for the planning of sustainable management strategies that include a rational use and the preservation of the coastal systems. Considering that this study took place 20 years ago and that the species list was updated with data from 1991 to the present, it establishes a baseline from which future studies may compare the biodiversity in the lagoon and its state of conservation, identify changes in hydrologic conditions and judge potential socio-economic effects in the area. In the case of fish and fisheries, it is important that regulatory measures be enforced to protect both the populations and the habitats.

\section{ACKNOWLEDGEMENTS}

The authors thank the Instituto de Ciencias del Mar y Limnología, Universidad Nacional Autónoma de México (UNAM) for support in carrying out this study, and the Comisión Nacional para el Conocimiento y Uso de la Biodiversidad (CONABIO) project $\mathrm{H} 258$ for financing.

\section{REFERENCES}

Abarca-Arenas L.G., Franco-López J., GonzálezGándara C., Silva-López G. 2012. [11] Los peces de la costa veracruzana: relación especies-área y conectividad entre sitios. Pp.127-158. In: del Moral Flores L.F., Martínez Pérez J.A., Franco López J., Ramírez Villalobos Á.J., Tello Musi J.L. (eds.) Investigación ictiológica en México: temas selectos en honor al Dr. José Luis Castro Aguirre. Universidad Nacional Autónoma de México, Facultad de Estudios Superiores Iztacala, Mexico. Vol. 304.

Aguirre-León A., Pérez-Ponce H.E., Díaz-Ruiz S. 2014. Heterogeneidad ambiental y su relación con la diversidad y abundancia de la comunidad de peces en un sistema costero del Golfo de México. Revista de Biología Tropical 62 (1): 145-163. DOI: 10.15517/ rbt.v62i1.8212

Aguirre-Macedo M.L., Vidal-Martínez V.M., GonzálezSolís D., Caballero P.I. 2007. Helminth communities of four commercially important fish species from Chetumal Bay, Mexico. Journal of Helminthology 81 (1): 19-31. DOI: 10.1017/S0022149X0721209X

Allen G.R. 1985. FAO species catalogue. Snappers of the world. An annotated and illustrated catalogue of lutjanid species known to date. FAO, Rome.

Anonymous 2010. Norma Oficial Mexicana NOM059-SEMARNAT-2010. Protección ambiental Especies nativas de México de flora y fauna silvestres - Categorías de riesgo y especificaciones para su inclusión, exclusión o cambio - Lista de especies en riesgo. Secretaría de Medio Ambiente y Recursos Naturales. Diario Oficial de la Federación, Diciembre 30, 2010. México.

Anonymous 2012a. Carta Nacional Pesquera. Diario Oficial de la Federación, Segunda Sección. Secretaría de Agricultura, Ganadería, Desarrollo Rural, Pesca y Alimentación. Agosto 24, 2012. México.

Anonymous 2012b. Status of the fisheries of Mexico. Diario Oficial. Secretaría de Agricultura, Ganadería, Desarrollo Rural, Pesca y Alimentación. México.

Anonymous 2014. Acuerdo por el que se da a conocer el Plan de Manejo Pesquero de Lisa (Mugil cephalus) y Lebrancha (Mugil curema) en las costas de Tamaulipas y Veracruz. Diario Oficial de la Federación, Marzo 31, 2014. México.

Anonymous 2015a. Global Capture Production. FAO, Fisheries and Aquaculture Department. [Accessed 
in September 2018.] http://www.fao.org/fishery/ statistics/global-capture-production/en

Anonymous 2015b. Programa de Manejo Área de Protección de Flora y Fauna Laguna Madre y Delta del Río Bravo. Secretaría de Medio Ambiente y Recursos Naturales and Comisión Nacional de Áreas Naturales Protegidas, México.

Ayala-Pérez L.A., Ramos-Miranda J., Flores-Hernández D. 2003. Estructura de la comunidad de peces en el sistema Candelaria-Panlau, Campeche, México. Revista de Biología Tropical 51 (3-4): 783-794.

Ayala-Pérez L.A., Ramos-Miranda J., FloresHernández D., Sosa A., Martínez G.E. 2015. Ictiofauna Marina y Costera de Campeche. Universidad Autónoma de Campeche, Universidad Autónoma Metropolitana-Xochimilco, México.

Ayala-Pérez L.A., Ramos-Miranda J., FloresHernández D., Vega-Rodríguez B.I., MorenoMedina U.C. 2008. Biological and ecological characterization of the catfish Cathorops melanopus off the west coast of Campeche, Mexico. Ciencias Marinas 34 (4): 453-465.

Ayala-Pérez L.A., Vasco-Villa O., Sosa-López A. 2014. Evaluación de las asociaciones de peces dominantes influenciadas por el ciclo nictemeral y la variación temporal en la Reserva de la Biósfera Los Petenes, Campeche, México. CienciaUAT 9 (1): 33-43. DOI: 10.29059/cienciauat.v9i1.618

Barba Macías E. 1999. Variación de la densidad y la biomasa de peces juveniles y decápodos epibénticos de la región central de Laguna Madre, Tamaulipas. Hidrobiológica 9 (2): 103-116.

Bardach J.E., Ryther J.H., McLarney W.O. 1972. Aquaculture: The farming and husbandry of freshwater and marine organisms. Wiley-Interscience, New York NY, USA.

Bigelow H.B., Schroeder W.C. 1948. Fishes of the western North Atlantic, Part one; lancelets, cyclostomes, sharks. Memoir, Sears Foundation for Marine Research, No. 1. Yale University, New Haven CT, USA.

Bigelow H.B., Schroeder W.C. 1953. Fishes of the western North Atlantic. Part two, sawfishes, guitarfishes, skates and rays; chimaeroids. Memoir, Sears Foundation for Marine Research, No. 1. Yale University, New Haven CT, USA.

Blanchet H., Van Hoose M., McEachron L., Muller B., Warren J., Gill J., Waldrop T., Walker J., Adams C., Ditton R.B., Shively D., VanderKooy S. 2001. The spotted seatrout fishery in the Gulf of Mexico, United States: A regional management plan. Publication No. 87.Gulf States Marine Fisheries Commission, Ocean Springs MS, USA.

Boström C., Bonsdorff E. 2000. Zoobenthic community establishment and habitat complexity-The importance of seagrass shoot-density, morphology and physical disturbance for faunal recruitment. Marine Ecology Progress Series 205: 123-138. DOI: 10.3354/ meps 205123
Bouchereau J.-L., Cordonnier S., Nelson L. 2012. Structure, reproduction, and diet of Lophogobius cyprinoides (Gobiidae) in a lagoon of Guadeloupe (French West Indies). Cahiers de Biologie Marine 53 (1): 1-16.

Cambray J., Swartz E. 2007. Oreochromis mossambicus. The IUCN Red List of Threatened Species 2007: e.T63338A12659743. [Downloaded on 4 July 2018.] DOI: 10.2305/IUCN.UK.2007.RLTS. T63338A12659743.en

Carpenter K.E., MacDonald T., Russell B., VegaCendejas M. 2014. Archosargus probatocephalus. The IUCN Red List of Threatened Species 2014: e.T170223A1296293. [Downloaded on 9 March 2018.] DOI: 10.2305/IUCN.UK.2014-3.RLTS. T170223A1296293.en

Carrillo-Alejandro P., Beléndez-Moreno L.F.J., Quiroga-Brahms C., González-Cruz A., GómezOrtiz M.G., Medellín-Ávila M., Leo-Peredo A.S., Márquez-García E., Villanueva-Fortanelli J.J., Castañeda-Chávez M.R., Lango-Reynoso F., Galaviz-Villa I., Soto-Alva J.M., Ríos-Massé A.D., Palomino-Ramírez O., Martínez-Pérez G., Rangel-Arteaga B.Y., Pantoja-Yepez G., GarcíaSolorio L., Acosta-Barbosa G., Balderas-Téllez J., Arteaga-Peña R., González-Rangel J.A., GómezJiménez J.L., Conde-Galaviz E., Martínez-Cruz L.E., Pantoja-González L.M. 2014a. [Plan de Manejo Pesquero.] Laguna Pueblo Viejo, Veracruz. Pp. 279-357. In: Beléndez Moreno L.F.J., Espino Barr E., Galindo Cortes G., Gaspar-Dillanes M.T., Huidobro Campos L., Morales Bojórquez E. (eds.) Sustentabilidad y Pesca Responsable en México. Evaluación y Manejo. SAGARPA \& Instituto Nacional de Pesca, México.

Carrillo-Alejandro P., Beléndez-Moreno L.F.J., Quiroga-Brahms C., Lorán-Núñez R.M., RolandoMartínez Isunza F., Paat J.A., González-Ocaranza L., Villanueva-Fortanelli J.J., Castañeda-Chávez M.R., Lango-Reynoso F., Galaviz-Villa I., SilvaLópez G., Abarca-Arena L.G., Rangel-Arteaga B.Y., Pantoja-González L.M., Arias-Cruz L., Martínez-Cruz L.E., Pantoja-Yépez G., EscartínHernández R., Garduño-Dionate M., NavaAbarca M., Morales-García G., Rivas-Villegas J., Romero-Hernández E., Lagunas M., CastilloHernández J. 2014b. [Plan de Manejo Pesquero.] Sistema Lagunar de Alvarado, Veracruz. Pp. 359-463. In: Beléndez Moreno L.F.J., Espino Barr E., Galindo Cortes G., Gaspar-Dillanes M.T., Huidobro Campos L., Morales Bojórquez E. (eds.) Sustentabilidad y Pesca Responsable en México. Evaluación y Manejo. SAGARPA \& Instituto Nacional de Pesca, México.

Castillo-Rivera M., Zárate Hernandez R. 2001. Patrones espacio-temporales de la abundancia de peces en la Laguna de Pueblo Viejo, Veracruz. Hidrobiológica 11 (1): 75-84.

Castillo-Rivera M., Zárate R., Ortiz S. 2005. Variación nictímera y estacional de la abundancia, riqueza y 
especies dominantes de peces, en un ambiente salobre de sustrato blando. Hidrobiológica 15 (2): 227-238.

Castro-Aguirre J.L., Espinosa Pérez H., SchmitterSoto J.J. 1999. Ictiofauna estuarino-lagunar y vicaria de México. Limusa Noriega Editores, México.

Chao L., Espinosa-Perez H. 2015a. Micropogonias undulatus. The IUCN Red List of Threatened Species 2015: e.T193268A49228279. [Downloaded on 9 March 2018.] DOI: 10.2305/IUCN.UK.2015-2.RLTS. T193268A49228279.en

Chao L., Espinosa-Perez H. 2015b. Bairdiella chrysoura. The IUCN Red List of Threatened Species 2015: e.T193264A49231845. [Downloaded on 9 March 2018.] DOI: 10.2305/IUCN.UK.2015-2.RLTS. T193264A49231845.en

Chavez-Lopez R., Franco-Lopez J. 1993. Respuesta de una comunidad de peces ante un impacto ambiental en Boca Camaronera, Alvarado, Veracruz. Hidrobiológica 2 (1-2): 25-33.

Chavez López R., Rocha Ramírez A., Ramírez Rojas A. 2005. Cambios en los ensamblajes de peces del sistema lagunar de Alvarado (SLA), Veracruz, México. Revista Digital Universitaria 6 (8): e79.

Cid A., Raz Guzmán A. 2011. Alternativas de manejo en la pesquería de camarón en las lagunas de Tamiahua y Madre. CONABIO Biodiversitas 95: 1-7.

Coad B.W., Reist J.D. 2004. Annotated list of the Arctic marine fishes of Canada. Canadian Manuscript Report of Fisheries and Aquatic Sciences No. 2674.

Compagno L.J.V. 1984. FAO species catalogue. Vol. 4. Sharks of the World: An annotated and illustrated guide of shark species known to date. Part 2. Carcharhiniformes. FAO Fisheries Synopsis No. 125, FAO, Rome.

Contreras-Balderas S., Almada-Villela P. 1996. Poecilia latipunctata. The IUCN Red List of Threatened Species 1996: e.T17832A7522300. [Downloaded on 12 February 2018.] DOI: 10.2305/IUCN.UK.1996. RLTS.T17832A7522300.en

de Moor I.J., Bruton M.N. 1988. Atlas of alien and translocated indigenous aquatic animals in southern Africa. A report of the Committee for Nature Conservation Research, National Programme for Ecosystem Research, Foundation for Research Development. South African Scientific Programmes Report No. 144. Foundation for Research Development, Council for Scientific and Industrial Research, Pretoria, South Africa.

Díaz-Ruiz S., Aguirre-León A., Mendoza-Sánchez E., Lara-Domínguez A.L. 2018. Factores ambientales que influyen en la ictiofauna de la laguna La Mancha, sitio Ramsar, Golfo de México. Revista de Biología Tropical 66 (1): 246-265. DOI: 10.15517/rbt.v66i1.28495

Díaz-Ruiz S., Aguirre-León A., Pérez-Solís O. 2000. Distribución y abundancia de Syngnathus louisianae y Syngnathus scovelli (Syngnathidae) en la Laguna de Tamiahua, Golfo de México. Ciencias Marinas 26 (1): 125-143. DOI: $10.7773 / \mathrm{cm} . v 26 i 1.567$
Díaz-Ruiz S., Pérez-Hernández M.A., Aguirre-León A. 2003. Characterization of fish assemblages in a tropical coastal lagoon in the northwest Gulf of Mexico. Caracterización de los conjuntos de peces en una laguna costera tropical del noroeste del Golfo de México. Ciencias Marinas 29 (4B): 631-644. DOI: 10.7773/cm.v29i42.189

Edgar G.J., Shaw C., Watson G.F., Hammond L.S. 1994. Comparisons of species richness, size structure and production of benthos in vegetated and unvegetated habitats in Western Port, Victoria. Journal of Experimental Marine Biology and Ecology 176 (2): 201-226. DOI: 10.1016/0022-0981(94)90185-6

Elliott M., Whitfield A.K., Potter I.C., Blaber S.J., Cyrus D.P., Nordlie F.G., Harrison T.D. 2007. The guild approach to categorizing estuarine fish assemblages: A global review. Fish and Fisheries 8 (3): 241-268. DOI: 10.1111/j.1467-2679.2007.00253.x

Franco A., Franzoi P., Torricelli P. 2008. Structure and functioning of Mediterranean lagoon fish assemblages: A key for the identification of water body types. Estuarine, Coastal and Shelf Science 79 (3): 549-558. DOI: 10.1016/j.ecss.2008.05.011

Franco-López J., Abarca-Arenas L.G., Bedia-Sánchez C., Barrera-Escorcia H., Silva-Contreras G. 2012. [19] Comportamiento de la comunidad ictiofaunística, ante los cambios ambientales a nivel local y regional en la Laguna de Alvarado. Pp. 259-283. In: del Moral Flores L.F., Martínez Pérez J.A., Franco López J., Ramírez Villalobos Á.J., Tello Musi J.L. (eds.) Investigación ictiológica en México: temas selectos en honor al Dr. José Luis Castro Aguirre. Universidad Nacional Autónoma de México, Facultad de Estudios Superiores Iztacala, Mexico. Vol. 304.

Franco-López J., Chavez-López R. 1993. Síntesis sobre el conocimiento de la ictiofauna de la Laguna de Tamiahua, Veracruz, México. Hidrobiológica 2 (1-2): 53-63.

Fraser T., Gilmore G. 2015a. Diapterus auratus. The IUCN Red List of Threatened Species 2015: e.T185971A1796616. [Downloaded on 9 March 2018.] DOI: 10.2305/IUCN.UK.2015-2.RLTS. T185971A1796616.en

Fraser T., Gilmore G. 2015b. Eucinostomus melanopterus. The IUCN Red List of Threatened Species 2015: e.T185993A1800179. [Downloaded on 9 March 2018.] DOI: 10.2305/IUCN.UK.2015-2. RLTS.T185993A1800179.en

Fricke R., Eschmeyer W.N., van der Laan R. (eds.) 2018. Catalog of fishes: Genera, species, references. [Accessed on 4 November 2018.] http:// researcharchive.calacademy.org/research/ichthyology/ catalog/fishcatmain.asp

Froese R., Pauly D. (eds.) 2018. FishBase. [Version 06/2018] http://www.fishbase.org

García-Cubas A., Reguero M. 2004. Catálogo ilustrado de moluscos gasterópodos del Golfo de México y Mar Caribe. Universidad Nacional Autónoma de México, Ciudad de México, México. 
García-Cubas A., Reguero M. 2007. Catálogo ilustrado de moluscos bivalvos del Golfo de México y Mar Caribe. Universidad Nacional Autónoma de México, Ciudad de México, México.

Gaspar-Dillanes M.T., Barba-Torres J.F. 2004. Peces de la Laguna de Tamiahua, Veracruz, México. Pp. 141191. In: Lozano-Vilano M.L., Contreras-Balderas A.J. (eds.) Libro Homenaje al Dr. Andrés Reséndez Medina. Un ictiólogo mexicano. Dirección de Publicaciones, Universidad Autónoma de Nuevo León, México.

Gupta M.V., Acosta B.O. 2004. A review of global tilapia farming practices. Aquaculture Asia 9 (1): 7-12 and 16.

Harrison D.T., Whitfield A.K. 2006. Estuarine typology and the structuring of fish communities in South Africa. Environmental Biology of Fishes 75 (3): 269293. DOI: 10.1007/s10641-006-0028-y

Heck K.L.jr., Crowder L.B. 1991. [14] Habitat structure and predator-prey interactions in vegetated aquatic systems. Pp. 281-299. DOI: 10.1007/978-94-0113076-9 14 In: Bell S.S., McCoy E.D., Mushinsky H.R. (eds.) Habitat structure: The physical arrangement of objects in space. Springer-Science+Bussiness Media, Dordrecht, the Netherlands . DOI: 10.1007/978-94011-3076-9

Ibáñez Aguirre A.L., Lleonart J. 1996. Relative growth and comparative morphometrics of Mugil cephalus L. and M. curema V. in the Gulf of Mexico. Scientia Marina 60 (2-3): 361-368.

Kottelat M., Whitten T. 1996. Freshwater biodiversity in Asia, with special reference to fish. World Bank Technical Papers No. 343.

Krebs C. 2008. The ecological world view. CSIRO Publishing, Collingwood, Victoria, Australia.

Lamboj A. 2004. The cichlid fishes of western Africa. Birgit Schmettkamp Verlag, Bornheim, Germany.

Lindeman K., Anderson W., Carpenter K.E., Claro R., Cowan J., Padovani-Ferreira B., Rocha L.A., Sedberry G., Zapp-Sluis, M. 2016a. Lutjanus griseus. The IUCN Red List of Threatened Species 2016: e.T192941A2180367. [Downloaded on 9 March 2018.] DOI: 10.2305/IUCN.UK.2016-1.RLTS. T192941A2180367.en

Lindeman K., Anderson W., Carpenter K.E., Claro R., Cowan J., Padovani-Ferreira B., Rocha L.A., Sedberry G., Zapp-Sluis M. 2016b. Lutjanus cyanopterus. The IUCN Red List of Threatened Species 2016: e.T12417A506633. [Downloaded on 9 March 2018.] DOI: 10.2305/IUCN.UK.2016-1.RLTS. T12417A506633.en

Lindeman K., Anderson W., Carpenter K.E., Claro R., Cowan J., Espinosa-Pérez H., Padovani-Ferreira B., Rocha L.A., Sedberry G., Zapp-Sluis M. 2016 c. Lutjanus apodus. The IUCN Red List of Threatened Species 2016: e.T155152A726254. [Downloaded on 9 March 2018.] DOI: 10.2305/IUCN.UK.2016-1.RLTS. T155152A726254.en

López-López E., Sedeño-Díaz J.E., Romero F.L., Trujillo-Jiménez P. 2009. Spatial and seasonal distribution patterns of fish assemblages in the Río
Champotón, southeastern Mexico. Reviews in Fish Biology and Fisheries 19 (2): 127-142. DOI: 10.1007/ s11160-008-9093-y

Macossay-Cortéz A., Sánchez A.J., Florido R., Huidobro L., Montalvo-Urgel H. 2011. Historical and environmental distribution of ichthyofauna in the tropical wetland of Pantanos de Centla, southern Gulf of Mexico. Acta Ichthyologica et Piscatoria 41 (3): 229-245. DOI: 10.3750/AIP2011.41.3.11

Maitipe P., De Silva S.S. 1985. Switches between zoophagy, phytophagy and detritivory of Sarotherodon mossambicus (Peters) populations in twelve manmade Sri Lankan lakes. Journal of Fish Biology 26 (1): 49-61. DOI: 10.1111/j.1095-8649.1985.tb04240.x

Marceniuk A.P., Menezes N.A. 2007. Systematics of the family Ariidae (Ostariophysi, Siluriformes), with a redefinition of the genera. Zootaxa 1416 (1): 1-126. DOI: 10.11646/zootaxa.1416.1.1

Masonjones H., Hayashida-Boyles A., Pollom R. 2017. Hippocampus zosterae. The IUCN Red List of Threatened Species 2017: e.T10089A46910143. [Downloaded on 12 February 2018.] DOI: 10.2305/ IUCN.UK.2017-3.RLTS.T10089A46910143.en

Masonjones H.D., Rose E., McRae L.B., Dixson D.L. 2010. An examination of the population dynamics of syngnathid fishes within Tampa Bay, Florida, USA. Current Zoology 56 (1): 118-133.

Matsuura K., Robertson R., TylerJ.2015. Aluterus schoepfii (errata version published in 2017). The IUCN Red List of Threatened Species 2015: e.T16404974A115354409. [Downloaded on 9 March 2018.] DOI: 10.2305/IUCN. UK.2015-4.RLTS.T16404974A16510262.en

McEachran J.D., Fechhelm J.D. 1998. Fishes of the Gulf of Mexico. Vol. 1: Myxiniformes to Gasterosteiformes. University of Texas Press, Austin TX, USA.

McEachran J.D., Fechhelm J.D. 2005. Fishes of the Gulf of Mexico. Vol. 2: Scorpaeniformes to Tetraodontiformes. University of Texas Press, Austin TX, USA.

Miller R.R., Minckley W.L., Norris S.M. 2005. Freshwater fishes of Mexico. The University of Chicago Press, Chicago IL, USA.

Munroe T.A. 2002. Achiridae. American soles. Pp. 1925-1933. In: Carpenter K.E. (ed.) The living marine resources of the western central Atlantic. Vol. 3: Bony fishes part 2 (Opistognathidae to Molidae), sea turtles and marine mammals. FAO Species Identification Guide for Fishery Purposes and American Society of Ichthyologists and Herpetologists Special Publication No. 5. FAO, Rome.

Munroe T.A.2015.Symphurus civitatium. The IUCNRedList of Threatened Species 2015: e.T16777231A16782003. [Downloaded on 7 July 2018.] DOI: 10.2305/IUCN. UK.2015-4.RLTS.T16777231A16782003.en

Munroe T.A., Baltz D.M., Allen R.L., Ross S.W. 2000. Symphurus civitatium (Pleuronectiformes: Cynoglossidae), a second estuarine-occurring tonguefish off the southeastern United States and northern Gulf of Mexico. Estuaries 23 (4): 439-448. DOI: $10.2307 / 1353137$ 
Nelson J.S., Grande T.C., Wilson M.V.H. 2016. Fishes of the world. 5th edn. John Wiley and Sons, Hoboken NJ, USA.

Ocaña-Luna A., Sánchez-Ramírez M. 2003. Diversity of ichthyoplankton in Tampamachoco Lagoon, Veracruz, Mexico. Anales del Instituto de Biología, Universidad Nacional Autónoma de México, Serie Zoología 74 (2): 179-193.

Ocaña-Luna A., Sánchez-Ramírez M. 2016. Estructura de la comunidad ictioplanctónica en la Laguna de Tamiahua, Veracruz, México. Revista Mexicana de Biodiversidad 87 (1): 123-132. DOI: 10.1016/j. rmb.2016.01.018

Page L.M., Burr B.M. 1991. Freshwater fishes: A field guide to freshwater fishes of North America north of Mexico. Peterson Field Guide Series. Houghton Mifflin, Boston MA, USA.

Peralta-Meixueiro M.A., Vega-Cendejas M.E. 2011. Spatial and temporal structure of fish assemblages in a hyperhaline coastal system: Ría Lagartos, Mexico. Neotropical Ichthyology 9 (3): 673-682. DOI: 10.1590/S1679-62252011005000033

Pérez H.E. 2007. Ecología de las Comunidades de Peces en Lagunas Costeras del Litoral de Veracruz, México. Servicio Social. Departamento de Hidrobiología, Universidad Autónoma Metropolitana-Iztapalapa, México.

Pérez-Hernández M.A., Torres-Orozco R.E. 2000. Evaluación de la riqueza de especies de peces en las lagunas costeras mexicanas: Estudio de un caso en el Golfo de México. Revista de Biología Tropical 48 (2-3): 425-438.

Pessanha A.L.M., Araújo F.G. 2014. Shifts of the feeding niche along the size dimension of three juvenile fish species in a tidal mudflat in southeastern Brazil. Marine Biology 161 (3): 543-550. DOI: 10.1007/ s00227-013-2356-8

Poot-Salazar A., Pérez-Castañeda R., Vega-Candejas M.E., Defeo O. 2009. Assessing patterns of ichthyofauna discarded by an artisanal shrimp fishery through selectivity experiments in a coastal lagoon. Fisheries Research 97 (3): 155-162. DOI: 10.1016/j. fishres.2009.02.001

Raz-Guzmán A., Barba E. 2000. Seagrass biomass, distribution and associated macrofauna in southwestern Gulf of Mexico coastal lagoons. Biologia Marina Mediterranea 7 (2): 271-274.

Raz-Guzmán A., Huidobro L. 2002. Fish communities in two environmentally different estuarine systems of Mexico. Journal of Fish Biology 61 (Suppl. A): 182195. DOI: 10.1111/j.1095-8649.2002.tb01770.x

Raz-Guzmán A., Sánchez A.J. 1996a. Trophic structure related to seagrass habitat complexity. Pp. 241-248. In: Kuo J., Phillips R.C., Walker D.I., Kirkman H. (eds.) Seagrass Biology. Proceedings of an International Workshop. Rottnest Island, Western Australia. 2529 January 1996. University of Western Australia, Crawley WA, Australia.
Raz-Guzmán A., Sánchez A.J. 1996b. Catálogo ilustrado de cangrejos braquiuros (Crustacea) de la Laguna de Tamiahua, Veracruz, México. Cuadernos de Instituto de Biología, Universidad Nacional Autónoma de México No. 31 .

Raz-Guzmán A., Sánchez A.J. 1998. Catálogo con sinonimias y notas sobre el hábitat de los cangrejos ermitaños estuarinos del suroeste del Golfo de México. Universidad y Ciencia (Ecosistemas y Recursos Agropecuarios) 14 (26): 17-31.

Raz-Guzmán A., Soto L.A. 2017. Updated checklist and zoogeographic remarks of benthic amphipods (Crustacea, Peracarida, Amphipoda) of two coastal lagoons in the western Gulf of Mexico. Revista Mexicana de Biodiversidad 88 (3): 715-734. DOI: 10.1016/j.rmb.2017.07.002

Renfro W.C. 1962. Small beam net for sampling postlarval shrimp. United States Fisheries and Wildlife Service Circular 161.

Reséndez-Medina A., Kobelkowsky-Díaz A. 1991. Ictiofauna de los sistemas lagunares costeros del Golfo de México, México. Universidad y Ciencia (Ecosistemas y Recursos Agropecuarios) 8 (15): 91-110.

Robins C.R., Ray G.C. 1986. A field guide to Atlantic coast fishes of North America. Houghton Mifflin, Boston MA, USA.

Rodger R.W.A., von Zharen W.M. 2012. Introduction to the commercial fisheries of the United States and Canada. Canadian Marine Publications, Halifax NS, Canada.

Rodríguez-Varela A.C., Cruz-Gómez A., VázquezLópez H. 2010. List of the ichthyofauna in the Sontecomapan Lagoon, Veracruz, Mexico. Biocyt 3 (9): 107-121.

Sánchez A., Raz-Guzmán A. 1997. Distribution patterns of tropical estuarine brachyuran crabs in the Gulf of Mexico. Journal of Crustacean Biology 17 (4): 609-620. DOI: $10.2307 / 1549364$

Sánchez A.J., Raz-Guzmán A., Barba E. 1996. Habitat value of seagrasses for decapods in tropical coastal lagoons of the southwestern Gulf of Mexico: An overview. Pp. 233-240. In: Kuo J., Phillips R.C., Walker D.I., Kirkman H. (eds.) Seagrass biology. Proceedings of an International Workshop. Rottnest Island, Western Australia. 25-29 January 1996. The University of Western Australia, Crawley WA, Australia.

Sánchez-Ramírez M., Ocaña-Luna A. 2015. Estructura y variación estacional de la comunidad ictioplanctónica en una laguna hipersalina del oeste del Golfo de México: Laguna Madre, Tamaulipas. Hidrobiológica 25 (2): 175-186.

Sanvicente-Añorve L., Sánchez-Ramírez M., OcañaLuna A., Flores-Coto C., Ordóñez-López U. 2011. Metacommunity structure of estuarine fish larvae: The role of regional and local processes. Journal of Plankton Research 33 (1): 179-194. DOI: 10.1093/ plankt/fbq098 
Scott W.B., Scott M.G. 1988. Atlantic fishes of Canada. Canadian Bulletin of Fisheries and Aquatic Sciences No. 219.

Seitz R.D., Wennhage H., Bergström U., Lipcius R.N., Ysebaert T. 2014. Ecological value of coastal habitats for commercially and ecologically important species. ICES Journal of Marine Science 71 (3): 648-665. DOI: $10.1093 /$ icesjms/fst152

Short F.T., Polidoro B., Livingstone S.R., Carpenter K.E., Salomão B., Bujang J.S., Calumpong H.P., Carruthers T.J.B., Coles R.G., Dennison W.C., Erftemeijer P.L.A., Fortes M.D., Freeman A.S., Jagtap T.G., Kamal A.H.M., Kendrick G.A., Kenworthy W.J., La Nafie Y.A., Nasution I.M., Orth R.J., Prathep A., Sanciangco J.C., van Tussenbroek B., Vergara S.G., Waycott M., Zieman J.C. 2011. Extinction risk assessment of the world's seagrass species. Biological Conservation 144 (7): 1961-1971. DOI: $10.1016 /$ j.biocon.2011.04.010

Smith C.L. 1997. National Audubon Society field guide to tropical marine fishes of the Caribbean, the Gulf of Mexico, Florida, the Bahamas, and Bermuda. Alfred A. Knopf, New York NY, USA.

Sokal R.R., Rohlf F.J. 1995. Biometry: The principles and practice of statistics in biological research. 3rd edn. Freeman, New York NY, USA.

Steimle F.W., Zetlin C.A., Berrien P.L., Johnson D.L., Chang S. 1999. Essential fish Habitat Source Document: Scup, Stenotomus chrysops, life history and habitat characteristics. NOAA Technical Memorandum NMFS-NE-149, NOAA, USA.

Terceiro M. 2012. Stock Assessment of Scup (Stenotomus chrysops) for 2012. US Department of Commerce, Northeast Fisheries Science Center Reference Document 12-25. Woods Hole MA, USA.

Thomson J.M. 1978. Mugilidae. In: Fischer W. (ed.) FAO species identification sheets for fishery purposes. Western Central Atlantic (fishing area 31). Vol. 3.. FAO, Rome.

Thurman II C.L. 1987. Fiddler crabs (genus Uca) of eastern Mexico (Decapoda, Brachyura, Ocypodidae). Crustaceana 53 (1): 94-105. DOI: $10.1163 / 156854087$ X00664
Trewavas E. 1982. Tilapias: taxonomy and speciation. Pp. 3-13. In: Pullin R.S.V., Lowe-McConnell R.H. (eds.) The Biology and Culture of Tilapias. ICLARM Conference Proceedings 7.

Tunnell J.W., Judd F.W. (eds.) 2002. The Laguna Madre of Texas and Tamaulipas. College Station, Texas A\&M University Press, College Station, TX, USA.

Vergara R. 1978. Stromateidae. In: Fischer W. (ed.) FAO Species Identification Sheets for Fishery Purposes. Western Central Atlantic (fishing area 31). Vol. 5. FAO, Rome.

Waycott M., Duarte C.M., Carruthers T.J.B., Orth R.J., Dennison W.C., Olyamik S., Calladine A., Fourqurean J.W., Heck K.L.jr., Hughes A.R., Kendrick G.A., Kenworthy W.J., Short F.T., Williams S.L. 2009. Accelerating loss of seagrasses across the globe threatens coastal ecosystems. Proceedings of the National Academy of Sciences of the United States of America 106 (30): 12377-12381. DOI: 10.1073 /pnas.0905620106

Yáñez-Arancibia A., Aguirre-León A. 1988. Pesquerías en la región de la Laguna de Términos. Pp. 431-452. In: Yáñez-Arancibia A., Day Jr. J.W. (eds.) Ecología de los Ecosistemas Costeros en el Sur del Golfo de México: la región de la Laguna de Términos. Editorial Universitaria, Instituto de Ciencias del Mar y Limnología, Universidad Nacional Autónoma de México and Coastal Ecology Institute, Louisiana State University. Mexico and USA.

Yáñez-Arancibia A., Lara-Domínguez A.L., RojasGalavíz J.L., Sánchez-Gil P., Day J.W.jr., Madden C.J. 1988. Seasonal biomass and diversity of estuarine fishes coupled with tropical habitat heterogeneity (southern Gulf of Mexico). Journal of Fish Biology 33 (Suppl. A): 191-200. DOI: 10.1111/j.1095-8649.1988. tb05573.x

Zavala-Hidalgo J., Morey S.L., O’Brien J.J. 2003. Seasonal circulation on the western shelf of the Gulf of Mexico using a high-resolution numerical model. Journal of Geophysical Research 108 (C12): e3389. DOI: $10.1029 / 2003$ JC001879

Received: 24 April 2018

Accepted: 30 October 2018

Published electronically: 31 December 2018 